\title{
Pre-eruptive magmatic processes associated with the historical (218 +/- 14 aBP) explosive eruption of Tutupaca volcano (southern Peru)
}

\author{
Manrique Nelida ${ }^{1}$, Samaniego Pablo ${ }^{2,}{ }^{*}$, Medard Etienne ${ }^{2}$, Schiavi Federica ${ }^{2}$, Marino Jersy ${ }^{1}$, \\ Liorzou Celine ${ }^{3}$
}

1 Direcc Geol Ambiental \& Riesgo Geol, Observ Vulcanol INGEMMET, Urb Magisterial B-16, Arequipa, Peru.

2 Univ Clermont Auvergne, CNRS, IRD, Lab Magmas \& Volcans,OPGC, F-63000 Clermont Ferrand, France.

3 Univ Bretagne Occidentale, Inst Univ Europeen Mer, Lab Geosci Ocean, Rue Dumont dUrville, F29280 Plouzane, France.

* Corresponding author : Pablo Samaniego, email address : pablo.samaniego@ird.fr

\begin{abstract}
:
Magma recharge into a differentiated reservoir is one of the main triggering mechanisms for explosive eruptions. Here we describe the petrology of the eruptive products of the last explosive eruption of Tutupaca volcano (southern Peru) in order to constrain the pre-eruptive physical conditions (P-T-X-H2O) of the Tutupaca dacitic reservoir. We demonstrate that prior to the paroxysm, magma in the Tutupaca dacitic reservoir was at low temperature and high viscosity $(735+/-23$ degrees $\mathrm{C})$, with a mineral assemblage of plagioclase, low-Al amphibole, biotite, titanite, and Fe-Ti oxides, located at $8.8+/-1.6 \mathrm{~km}$ depth $(233+/-43 \mathrm{MPa})$. The phenocrysts of the Tutupaca dacites show frequent disequilibrium textures such as reverse zonation, resorption zones, and overgrowth rims. These disequilibrium textures suggest a heating process induced by the recharge of a hotter magma into the dacitic reservoir. As a result, high$\mathrm{Al}$ amphibole and relatively high-Ca plagioclase phenocryst rims and microlites were formed and record high temperatures from just before the eruption $(840+/-45$ degrees $C)$. Based on these data, we propose that the recent eruption of Tutupaca was triggered by the recharge of a hotter magma into a highly crystallized dacitic magma reservoir. As a result, the resident dacitic magma was reheated and remobilized by a self-mixing process. These magmatic processes induced an enhanced phase of dome growth that provoked destabilization of the NE flank, producing a debris avalanche and its accompanying pyroclastic density currents.
\end{abstract}

Keywords : Tutupaca, Magma recharge, Self-mixing, Thermobarometry 
Introduction

39 triggering mechanisms of explosive eruptions. Several processes have been invoked as triggers

40 of such events, including: (1) recharge of a differentiated reservoir by primitive magmas

41 followed by magma mixing (e.g. Pinatubo 1991; Pallister et al. 1992), (2) self-mixing between

42 magmas with the same composition but different temperatures and volatile contents (e.g. 
Soufriere Hills, Montserrat 1995, Couch et al. 2001; Tungurahua 2006, Samaniego et al. 2011; Ubinas 2006, Rivera et al. 2014); (3) the occurrence of large regional earthquakes (e.g. PuyehueCordon Caulle 1960, Lara et al. 2004); and (4) the existence of a volatile-saturated magma reservoir (e.g. Galeras 1990, Stix et al. 1997; Chaitén 2008, Castro and Dingwell 2009; Calbuco 2015, Castruccio et al. 2016).

Tutupaca volcano, located in the southern part of the Peruvian volcanic arc (Central Volcanic Zone of the Andes) comprises a dacitic dome complex of Holocene age, which experienced a large explosive eruption in historical times (218 $\pm 14 \mathrm{aBP}$; Samaniego et al. 2015). This eruption was characterized by a sector collapse of the NE flank of the volcano, with the subsequent generation of a debris avalanche and a large sequence of pyroclastic density currents (Samaniego et al. 2015; Valderrama et al. 2016). The association between a debris avalanche and a collapse-triggered explosive eruption has been described in the literature ( $c f$. Belousov et al. 2007), most notably for the recent eruptions of Mt. St. Helens in 1980 (Hobblit et al. 1981), Bezymianny in 1956 (Belousov 1996) and Soufrière Hills in 1997 (Voight et al. 2002). The triggering mechanisms invoked for these eruptions include the presence of a pressurized magma body located at very shallow levels (cryptodome) for the Mt. St. Helens and Bezymianny eruptions, and a reinforced phase of dome growth for Soufrière Hills volcano.

In order to understand the magmatic processes and the triggering mechanism at work before the last Tutupaca eruption, we use the work of Samaniego et al. (2015) and Valderrama et al. (2016) as a foundation for a petrological study of the eruptive products of this eruption, focusing on samples of the pyroclastic density current deposits as well as on the pre-collapse domes. We also investigated some scarce magmatic enclaves found in the younger pre-collapse domes. Based on these data, we constrain the pre-eruptive physical conditions of the magmas (P- 
$\mathrm{T}-\mathrm{X}_{\mathrm{H} 2 \mathrm{O}}$ ), identify the petrological processes that occurred in the shallow reservoir, and propose a model in which magma recharge and self-mixing in a dacitic reservoir are the triggering mechanisms associated with this eruption.

\section{Geological setting}

The Tutupaca volcanic complex (TVC, $\left.17^{\circ} 01^{\prime} \mathrm{S}, 70^{\circ} 21^{\prime} \mathrm{W}\right)$ is located in the southern part of the Peruvian volcanic arc (Fig. 1a). It is part of the Central Volcanic Zone of the Andes, which results from subduction of the Nazca plate beneath the South American lithosphere. The TVC is constructed on top of a Mio-Pliocene plateau formed of ignimbritic and volcano-sedimentary deposits (Fidel and Zavala 2001; Thouret et al. 2007; Mamani et al. 2010). It is composed of a basal, lava-dominated, hydrothermally altered and glaciated edifice, as well as two younger cones here called the Western and Eastern edifices, located to the north of the complex (Samaniego et al. 2015). Structural development of the volcanic complex is controlled by regional normal faults with a sinistral component and a roughly $\mathrm{N} 140^{\circ}$ direction that have been mapped around Suches lake (Fig. 1b; Mariño et al. 2019). These structures are roughly parallel to the Incapuquio fault system, which is located in a forearc setting (not shown, Benavente et al. 2017).

Eastern Tutupaca (5815 meters above sea level) is the youngest edifice of the complex and is constructed on top of the hydrothermally-altered Basal Tutupaca edifice. It is composed of at least seven coalescent domes of dacitic composition ( $\left.64-66 \mathrm{wt} . \% \mathrm{SiO}_{2}\right)$ that are not affected by Pleistocene glaciations, suggesting a Holocene age (domes I to VII, Fig. 1b, 2a). The youngest dome (dome VII) contains scarce mafic enclaves (only 5 small enclave samples were collected 
Figure 2 2a).

Figure 1

during our fieldwork). The most conspicuous characteristic of this edifice is a $1 \mathrm{~km}$-wide horseshoe-shaped amphitheatre open to the NE. Eastern Tutupaca was affected by at least two sector collapses, whose deposits were dispersed in different directions: the older deposit was channelized through the Basal Tutupaca glacial valleys located to the E and SE of the volcano; whereas the younger deposit crops out immediately to the NE of the amphitheatre. A large explosive eruption of Tutupaca was radiocarbon dated at $218 \pm 14$ aBP (Samaniego et al. 2015). This age is corroborated by historical accounts describing a sustained explosive activity in the period between CE 1787 and 1802 (Zamácola y Jaúregui 1804; Valdivia 1847). This eruption was characterized by a sector collapse that triggered a debris avalanche and an associated explosive eruption (Fig. 1b) whose deposits spread out into the Paipatja plain to the NE of the complex. On the basis of detailed field work, Samaniego et al. (2015) and Valderrama et al. (2016) described the following deposits for the historical eruptions of Tutupaca: (1) a sequence of pre-avalanche block-and-ash flows exposed in the Zuripujo valley to the east of the Eastern Tutupaca summit (the Z-PDC deposits, Fig. 1b); (2) a debris avalanche (DA) deposit with two main units of different compositions and dynamic behaviours, which is well exposed toward the NE of the complex; and (3) a pyroclastic density current deposit, interlayered with the DA deposit, and covering the Paipatja plain to the NE of the volcano (the P-PDC deposit, Fig. 1b, 
Based on the studies of Samaniego et al. (2015) and Valderrama et al. (2016), we focus here on the historical volcanic products of the Eastern Tutupaca edifice. Two samples with contrasting textures, including a pumiceous bomb from the P-PDC (TU-12-06A) and a dense block from a pre-avalanche dome (TU-12-42), were used for modal analyses. We used highresolution (1200 dpi) images of thin sections scanned between two polarized sheets and Adobe Photoshop ${ }^{\circledR}$ software to do the image analysis, following the procedure described by Zhang et al. (2014). A different shade of grey was attributed to each mineral (plagioclase, amphibole, biotite, titanite, clinopyroxene, quartz, and Fe-Ti oxides), and these were distinguished from the matrix and the vesicles. We calculated the number of pixels for each mineral, as well as the total number of pixels in the image, to obtain the $2 \mathrm{D}$ modal percentages. Following Zhang et al. (2014) this method yields low ( $\pm 3 \%$ ) discrepancies with respect to 3D estimates.

Major and trace-element whole-rock analyses (Table 1) were obtained from agatecrushed powders of 37 samples at the Laboratoire Géosciences Océan, Université de Bretagne Occidentale (Brest, France), using an Inductively Coupled Plasma-Atomic Emission Spectrometer (ICP-AES) and following the analytical procedure described by Cotten et al. (1995). Relative standard deviation ( 2 sigma) is $\leq 1 \%$ for $\mathrm{SiO}_{2}, \leq 2 \%$ for the other major elements and $\leq 5 \%$ for trace elements. Major element compositions of minerals and glasses (Tables 2 to 6 ) were obtained at the Laboratoire Magmas et Volcans, Université Clermont Auvergne (ClermontFerrand, France), using a CAMECA SX-100 electron microprobe. Additional information concerning the analytical methods is included in the Supplementary material 1 . Trace element compositions for selected phenocrysts (Supplementary material 2) were obtained by LaserAblation-ICP-MS analyses, using a $193 \mathrm{~nm}$ Resonetics M-50E excimer laser coupled to an 
Agilent 7500cs ICP-MS. This technique uses calcium as an internal standard and measurements were calibrated relative to the NIST-612 glass. Standards NIST-612 and BCR was also measured to check the reliability of the results. The typical analytical error for most trace elements is < $10 \%$.

Water content in melt inclusions (Table 6) was determined at the Laboratoire Magmas et Volcans using a Renishaw InVia confocal microspectrometer equipped with a $532 \mathrm{~nm}$ diode laser (200 mW output power), a Peltier-cooled CCD detector, a motorized XYZ stage and a Leica DM2500 M optical microscope. We used an external calibration procedure and a set of hydrous glass standards (see Schiavi et al. 2018 for details about the method). Standard glasses were analysed at the same conditions as the samples. Under these analytical conditions the precision, calculated from repeated standard measurements (relative uncertainty), is usually better than $6 \%$.

\section{Petrological data}

Petrography

The dome rocks, the juvenile blocks of the DA deposits and the dense blocks of the PPDC deposits (Fig. 3a-f) are dark grey, porphyritic ( 35 vol.\% phenocrysts), partially vesiculated ( $\sim 5$ vol.\%) dacites with phenocrysts of plagioclase (15-20 vol.\%), amphibole (10-15 vol.\%), biotite (3-5 vol.\%), clinopyroxene (2-3 vol.\%) and Fe-Ti oxides (1-3 vol.\%), and with titanite, apatite and quartz as accessory phases $(<1 \mathrm{vol} . \%)$. The matrix is composed of interstitial glass, with abundant microlites $(<100 \mu \mathrm{m})$ of plagioclase, amphibole and Fe-Ti oxides. The P-PDC deposits also contain breadcrust-type bombs (Fig. 2 c,d) that are light grey, vesiculated $(\sim 15$ 
vol.\%), have porphyritic textures ( 15-20 vol.\% phenocrysts) and an identical mineral assemblage to the dense blocks. The scarce mafic magmatic enclaves are fine-grained and rounded $(2-10 \mathrm{~cm}$ in diameter), with a quench-textured groundmass constituted of randomly oriented, interlocking, elongate or acicular crystals (Fig. 3g). The main phases are tabular plagioclase $(150$ to $600 \mu \mathrm{m})$, acicular amphibole $(100$ to $350 \mu \mathrm{m})$ and biotite (100 to $250 \mu \mathrm{m})$ and scarce Fe-Ti oxides $(100-150 \mu \mathrm{m})$ in a mostly glassy, vesicular matrix. Also present in the enclaves are some large plagioclase phenocryst with sieve textures and subhedral amphiboles (up to 1-2 $\mathrm{mm})$, probably derived from the host dacite. In addition, a silicic enclave $(50 \times 30 \mathrm{~cm}$ in diameter) was sampled in a block from the older debris avalanche deposit of Eastern Tutupaca. This enclave has a microgranular texture (Fig. 3h), and is composed of euhedral to subhedral zoned plagioclase (40-45 vol.\%) with amphibole inclusions, subhedral quartz (5-7 vol.\%) with resorption rims, amphibole (3 vol.\%) with reaction rims, Fe-Ti oxides (1-2 vol.\%), biotite and titanite ( $<1$ vol.\%). This enclave has a glassy matrix with abundant microlites of plagioclase, amphibole and Fe-Ti oxides.

Figure 3

Whole-rock major and trace elements

The Holocene Tutupaca eruptive products are high-K calc-alkaline dacites (Fig. 4, Table 1) according to the classification of Peccerillo and Taylor (1976). All samples from the Eastern Tutupaca domes show very restricted dacitic compositions (64.4-66.1 wt.\% $\mathrm{SiO}_{2}$, normalized on an anhydrous basis). Dense juvenile blocks included in the DA and the P-PDC deposits have 
similar chemical characteristics $\left(64.5-65.9\right.$ wt.\% $\left.\mathrm{SiO}_{2}\right)$. In contrast, the bombs of the P-PDC deposits, especially the scarce pumiceous samples (67-68 wt.\% $\left.\mathrm{SiO}_{2}\right)$, and the silicic enclave (68 wt. $\% \mathrm{SiO}_{2}$ ) have slightly higher silica contents. The fine-grained enclaves are of basalticandesitic or andesitic compositions (53.0-57.9 wt.\% $\mathrm{SiO}_{2}$ ).

Comparisons between the younger (Eastern) and the older (Western and Basal Tutupaca) edifices of the Tutupaca complex show that, for most major elements, Eastern Tutupaca samples lie on the trend defined by the Basal and Western Tutupaca edifices (Fig. 4). This trend is characterized by a progressive decrease in major elements with silica increase, except for $\mathrm{K}_{2} \mathrm{O}$ that display a positive correlation with silica. Similarly, the overall Tutupaca magmatic trend is characterized by negative correlations of $\mathrm{Sr}$, some transition metals (e.g. V, the Middle Rare Earth Elements (MREE, e.g. Dy) and the Heavy Rare Earth Elements (HREE, e.g. Yb) with silica content. In contrast, the Large Ion Lithophile Elements (LILE, e.g. Th) are positively correlated with silica content (Fig. 4), whereas some scattering is observed for the Light Rare Earth Elements (LREE, e.g. La, Nd), and the High Field Strength Elements (HFSE, e.g. Zr, Nb, not shown). The most striking characteristic of Eastern Tutupaca eruptive products, however, is a slight enrichment in LREE (e.g. La) and Sr, and a notable depletion in the MREE (e.g. Dy) and HREE (e.g. Yb), which results in high La/Yb ratios (41-83) and Dy/Yb ratios (2.5-3.4) for the Eastern Tutupaca samples as compared to the whole Tutupaca volcanic complex (Fig. 4). Lastly, the mafic enclaves represent the most primitive compositions of this volcanic complex, and extend the Tutupaca magmatic trend towards low-silica concentrations.

Figure 4 
Mineral textures and chemistry

Plagioclase is the most abundant mineral in Tutupaca dacites (15-20 vol.\%) and appears as euhedral and subhedral phenocrysts and microlites. Phenocrysts have a wide range of compositions from $\mathrm{An}_{24}$ to $\mathrm{An}_{61}$, while microlites have more restricted compositions from $\mathrm{An}_{32}$ to $\mathrm{An}_{52}$. Two different groups of plagioclase phenocrysts are identified on the basis of textural characteristics: (1) a dominant first group (10-15 vol.\%), which includes euhedral and subhedral phenocrysts with normal zoning (e.g. $\mathrm{An}_{45 \rightarrow 22}$ ) and no evidence of disequilibrium (Fig. 3a), and (2) a subordinate group (5-10 vol.\%), which includes subhedral plagioclase with concentric resorption zones and/or overgrowth rims 10 to $35 \mu$ m-thick with An-rich compositions ( $\mathrm{An}_{42}$ to $\left.\mathrm{An}_{61}\right)$ and higher values of $\mathrm{FeO}^{*}$ (0.4 to 0.7 wt.\%, see below; Fig. 3b), phenocrysts with sieve textures, and oscillatory (e.g. $\mathrm{An}_{26 \rightarrow 35 \rightarrow 51 \rightarrow 30}$ ) or reverse (e.g. An $26 \rightarrow 55$ ) zoning patterns (Fig. 5a,b; Table 2). Amphibole is the second most abundant mineral phase in Tutupaca dacites (5-10 vol.\%). According to the classification scheme of Leake et al. (1997), amphibole phenocrysts from the PPDC, the lava domes and the enclaves include magnesio-hornblende, tschermakite, magnesiohastingsite and some scarce edenite compositions, whereas microlites from P-PDC samples are 
largely magnesio-hastingsite. Amphibole phenocrysts are commonly fresh (unaltered) and euhedral, although a small subset (see below) has oxidized cores and rims, and rarely the crystals are totally replaced by an aggregate of Fe-Ti oxides, pyroxenes and plagioclase (gabbroic-type alteration, Rutherford and Hill 1993; de Angelis et al. 2013).

Three different populations have been identified. Group 1 (3-7 vol.\%) includes euhedral and subhedral amphiboles (Fig. 3c, 300-1000 $\mu \mathrm{m}$ ) with low-Al compositions (6-7 wt. $\% \mathrm{Al}_{2} \mathrm{O}_{3}$ ), low Mg\# of 66 to 57 , with decreasing $\mathrm{Mg \#}$ toward the rim [where $\mathrm{Mg \#}=100 * \mathrm{Mg} /\left(\mathrm{Mg}+\mathrm{Fe}^{\mathrm{T}}\right)$, in $\mathrm{mol} \%$ and $\mathrm{Fe}^{\mathrm{T}}$ is total $\mathrm{Fe}$. The second group (2-3 vol.\%) is composed of phenocrysts with thin high-Al rim overgrowths $\left(10-20 \mu \mathrm{m} ; 8-11\right.$ wt. $\left.\% \mathrm{Al}_{2} \mathrm{O}_{3}\right)$ mantling a low-Al core (Fig. 3d, 5e,f), and displaying a sharp increase in Mg\# from core to rim (from 50 to 70; Fig. 5f; Table 3). Included in this group are amphibole microlites with high-Al compositions, similar to those of the phenocryst overgrowth rims. The third group corresponds to amphibole from the fine-grained mafic magmatic enclaves (Fig. 3g), which have high-Al compositions and normal Mg\# zoning (e.g. Mg\# $68 \rightarrow 62$ )

\section{Figure 5}

Table 3

Table 4

Biotite appears as euhedral and subhedral phenocrysts ( 3 vol.\%, up to $2 \mathrm{~mm}$ in diameter) as well as inclusions in plagioclase and amphibole phenocrysts. Some phenocrysts display a variation in 
261 wt. \%

FeO* (e.g. 15-19 wt.\%, Table 4) and MgO (e.g. 12-17 wt.\%). Some P-PDC biotites are oxidized, although the degree of oxidation varies from severe to mild from one crystal to another.

Clinopyroxene (3 vol.\%) is present as subhedral to euhedral phenocrysts (Fig. 3e, 100-300 $\mu \mathrm{m}$ ), as well as microlites $(10-50 \mu \mathrm{m})$. It is also observed as a reaction product of amphibole breakdown. Following the classification scheme of Morimoto et al. (1988), clinopyroxene phenocrysts are augites with largely uniform $\mathrm{Wo}_{41-44} \mathrm{En}_{41-45} \mathrm{Fe}_{12-16}$ compositions (Table 5) and commonly show slight reverse zoning with higher $\mathrm{Mg \#} \mathrm{rims}(70 \rightarrow 80)$.

Titanite is an accessory phase $(<1$ vol.\%) that appears as brown, zoned microphenocrysts and phenocrysts (Fig. 3b, 200-800 $\mu \mathrm{m}$ ) with euhedral, rhombic habits. Titanite phenocrysts contain abundant inclusions of $\mathrm{Fe}-\mathrm{Ti}$ oxides, while some titanite crystals also have reaction rims composed of Fe-Ti oxides. They display reverse (e.g. $1.3 \rightarrow 1.8$ wt.\% FeO*, Table 5) and oscillatory (e.g. $1.3 \rightarrow 1.8 \rightarrow 1.4$ wt.\% FeO*) zoning. Titanite does not appear in the mafic enclaves.

Fe-Ti oxides (1-2 vol.\%) are present as subhedral microphenocryst and microlites $(<100 \mu \mathrm{m})$ 8 dispersed in the groundmass and as inclusions in some phenocrysts like plagioclase, amphibole and titanite. Two types of oxides have been identified. Titanomagnetite display $\mathrm{TiO}_{2}$ concentrations ranging between 3.8 and 11.4 wt.\%, and ilmenite shows $\mathrm{TiO}_{2}$ values of 34.1-50.6 
Table 5

Trace elements in minerals

Trace element concentrations were measured in selected plagioclase, amphibole, titanite, biotite (not shown) and clinopyroxene phenocrysts from P-PDC and DA samples (Fig. 6, Supplementary material 2). The selected plagioclases correspond to the previously defined first group and exhibit a LREE enriched spectrum with a positive Eu anomaly and low concentrations of MREE and HREE. The compositional spectra for clinopyroxene are uniform and concave, showing high concentrations of MREE compared to LREE and HREE, and no Eu anomaly. Concerning amphibole, the high-Al phenocrysts display very homogeneous, REE fractionated, concave spectra with a small negative Eu anomaly, whereas the low-Al amphiboles display a wide REE variability, with LREE-enriched, HREE-depleted spectra and a strong negative Eu anomaly. Lastly, titanite analyses exhibit REE-fractionated spectra, characterized by extremely high values of all REE, and a slight negative Eu anomaly. In addition, for the plagioclase and amphibole phenocrysts, the core compositions display lower REE values than those of the rims (Fig. 6). It should be noted that the low-Al amphibole, and to a lesser extent high-Al amphibole and titanite, exhibit Eu negative anomalies, which indicates the contemporaneous crystallization of plagioclase, amphibole and titanite.

Figure 6 
Chemical composition of interstitial glass and melt inclusions Interstitial matrix glasses (MG) (Table 6) from recent dacitic samples display rhyolitic compositions (70-78 wt.\% $\mathrm{SiO}_{2}$, Fig. 7) with an average value of $74.4 \pm 2.3$ wt.\% $\mathrm{SiO}_{2}(\mathrm{n}=21, \mathrm{n}$ being the number of analyses) for P-PDC, and $73.8 \pm 2.8 \mathrm{wt} . \% \mathrm{SiO}_{2}(\mathrm{n}=2)$ for recent domes and debris avalanche blocks. When plotted on Harker diagrams, MG compositions show a wide scattering for some major elements $\left(\mathrm{K}_{2} \mathrm{O}, \mathrm{Al}_{2} \mathrm{O}_{3}, \mathrm{CaO}\right.$; Fig. 7) but they form an extension to the whole-rock data toward silica-rich compositions. These glass compositions are enriched in $\mathrm{K}_{2} \mathrm{O}$ (3.3-6.4 wt.\%, Fig. 7) compared to whole-rocks, and they show low concentrations of $\mathrm{Al}_{2} \mathrm{O}_{3}$ (9.9-17.1 wt.\%), $\mathrm{FeO}^{*}(0.7-1.6$ wt.\%), $\mathrm{CaO}(0.2-3.4$ wt.\%), and $\mathrm{MgO}(0.0-0.7$ wt.\%). These features suggest that scattering probably results from the presence of tiny (a few $\mu \mathrm{m}$ ) plagioclase microlites on the analysed spot. Plagioclase- and amphibole-hosted melt inclusions (MI) display much more uniform values (74-78 wt.\% $\left.\mathrm{SiO}_{2}\right)$, and they also plot at the high-silica end of the whole-rock magmatic trend. Water contents measured by Raman spectroscopy in plagioclasehosted MI range between 1.5 and $2.5(2.1 \pm 0.3 ; \mathrm{n}=11)$ wt.\%, whereas amphibole-hosted MI display slightly higher values, ranging from 1.5 to $3.7(2.5 \pm 0.8 ; n=9)$ wt. $\% \mathrm{H}_{2} \mathrm{O}$.

Table 6 
Experimental constraints

Pre-eruptive physical conditions ( $\mathrm{P}-\mathrm{T}-\mathrm{X}_{\mathrm{H} 2 \mathrm{O}}$ ) can be constrained by comparison of the mineral assemblage observed in Tutupaca dacites with experimental studies on analogous magma compositions. The dacitic magmas of Mt. St. Helens (Rutherford and Devine 1988), Pinatubo (Prouteau and Scaillet 2003) and Unzen (Holtz et al. 2005) have a similar major element composition to those of Tutupaca. Amphibole crystallization in these dacitic magmas places strong constraints in terms of P-T- $\mathrm{X}_{\mathrm{H} 2 \mathrm{O}}$. Amphibole is stable at $<900^{\circ} \mathrm{C}, 160-300 \mathrm{MPa}$, and a water content of between 4-6 wt.\% (Scaillet and Evans 1999; Prouteau and Scaillet 2003; Holtz et al. 2005). Biotite is stable at lower temperatures $\left(775-800^{\circ} \mathrm{C}\right)$ and pressures $(100-200$ MPa), while the water content can range between 5 and 7 wt.\% (Holtz et al. 2005; Castro and Dingwell 2009). The presence of titanite in dacitic magmas also provides additional constraints about the crystallization conditions. Experimental work on the Fish Canyon Tuff dacite (Hayden et al. 2008) shows that titanite crystallized at $745-780^{\circ} \mathrm{C}$, and a pressure of between $100-300$ MPa. Based on these experimental data, we suggest that Tutupaca dacitic magmas should have equilibrated at $750-800^{\circ} \mathrm{C}, 100-300 \mathrm{MPa}$ and should contain at least $4-6 \mathrm{wt} . \%$ water. We should stress that these are first-order estimates. Taking advantage of the ubiquitous presence of amphibole on Tutupaca samples, we applied several amphibole-based thermobarometers in order to better constrain the P-T- $\mathrm{X}_{\mathrm{H} 2 \mathrm{O}}$ conditions of Tutupaca dacites.

Amphibole stoichiometry

Amphibole compositions in calc-alkaline rocks are controlled by different substitutions that are function of pressure, temperature, and melt composition (Poli and Schmidt 1992; 
Bachmann and Dungan 2002; de Angelis et al. 2013). The main exchange mechanisms are: (1) the Tschermack substitution $\left[\mathrm{Si}_{(\mathrm{Tsite})}+\mathrm{Mg}_{(\mathrm{Csite})}={ }^{\mathrm{IV}} \mathrm{Al}_{(\mathrm{Tsite})}+{ }^{\mathrm{VI}} \mathrm{Al}_{(\mathrm{Csite})}\right]$; (2) the Ti-Tschermack substitution $\left[2 \mathrm{Si}_{(\mathrm{Tsite})}+\mathrm{Mg}_{(\mathrm{Csite})}=2{ }^{\mathrm{IV}} \mathrm{Al}_{(\mathrm{Tsite})}+\mathrm{Ti}_{(\mathrm{C} \text { site })}\right]$; and (3) the edenite substitution $\left[\mathrm{Si}_{(\mathrm{Tsite})}\right.$ $\left.+\square_{(\text {Asite })}={ }^{\mathrm{IV}} \mathrm{Al}_{(\mathrm{Tsite})}+(\mathrm{Na}+\mathrm{K})_{(\mathrm{Asite})}\right]$. The Tschermack substitution is correlated with crystallization pressure, whereas the Ti-Tschermack and edenite substitutions are mostly sensitive to temperature variations (Blundy and Holland 1990; Poli and Schmidt 1992; Holland and Blundy 1994).

Tutupaca amphiboles plot in two different groups defined by their ${ }^{\mathrm{IV}} \mathrm{Al}, \mathrm{Si}$ and $\mathrm{Na}+\mathrm{K}$ contents, whereas ${ }^{\mathrm{VI}} \mathrm{Al}$ and $\mathrm{Mg \#}$ are almost constant (Fig. 8). The difference between the two groups corresponds to an edenite substitution, implying a strong difference in temperature, but little variations in pressure. For the recent dacitic rocks (RD and P-PDC), the phenocrysts show both low and high ${ }^{\mathrm{IV}} \mathrm{Al}(0.8-1.3$ and $1.5-2.0$ atoms per formula unit -a.p.f.u.), whereas microlites show only high ${ }^{\mathrm{IV}} \mathrm{Al}$ content $(1.7-2.0)$ (i.e. high temperature). Amphiboles from the fine-grained mafic enclaves also have high ${ }^{\mathrm{IV}} \mathrm{Al}$ values (1.5 - 2.1 a.p.f.u.), and show a weak increase in ${ }^{\mathrm{VI}} \mathrm{Al}$ (up to 0.4 a.p.f.u.).

Figure 8 (n)

\section{Temperature}

The paragenesis of Tutupaca dacites is suitable for temperature estimates using amphibole-plagioclase geothermometry (Blundy and Holland 1990). The edenite-richterite and edenite-tremolite formulations of Holland and Blundy (1994) apply to silica undersaturated 
(quartz-free) and silica saturated assemblages, respectively. Although the Tutupaca dacites (and the silicic enclave) do contain scarce anhedral to subhedral quartz crystals (Fig. 3f), their rounded shapes and corrosion gulfs suggest these crystals might not be at equilibrium with the rest of the paragenesis. We thus applied the quartz-free edenite-richterite formulation to amphibole-plagioclase pairs that demonstrate textural evidence of equilibrium, including touching euhedral crystals, or inclusions of amphibole in plagioclase phenocrysts. In addition, because this thermometer is not very sensitive to pressure changes, we fixed the equilibrium pressure to $250 \mathrm{MPa}$ (see below). Different temperature estimates were obtained from low-Al amphiboles (phenocryst cores) and high-Al amphiboles (overgrowth rims of phenocrysts and microlites). Low-Al amphibole-plagioclase pairs yield temperatures in the range of 703 to $797^{\circ} \mathrm{C}$ (mean value of $\left.735 \pm 23^{\circ} \mathrm{C}, \mathrm{n}=20\right)$, whereas rather higher temperatures of 789 to $921^{\circ} \mathrm{C}(835 \pm$ $41^{\circ} \mathrm{C}, \mathrm{n}=20$ ) were obtained for high-Al amphibole-plagioclase pairs. In addition, amphiboleplagioclase pairs from the mafic enclaves also yield high temperatures $\left(791-921^{\circ} \mathrm{C}, 840 \pm 45^{\circ} \mathrm{C}\right.$, $\mathrm{n}=11$ ), consistent with values obtained from high-Al amphibole rims and microlites. Variations in ${ }^{\mathrm{IV}} \mathrm{Al}$ vs. temperature (T) in both amphibole groups (Fig. 9a) show similar relationships between the calculated $\mathrm{T}$ and the Mg\# (Fig. 9b), with the higher temperatures corresponding to those amphiboles that have both higher $\mathrm{Al}$ content and $\mathrm{Mg \#}$. This behaviour has been previously described for amphibole phenocrysts from Soufrière Hills volcano by Rutherford and Devine (2003).

Temperatures estimated using amphibole and plagioclase were corroborated with the $\mathrm{Zr}$ in-titanite thermometer (Hayden et al. 2008), which was calibrated for magmatic titanite in equilibrium with zircon, quartz and rutile. The $\mathrm{Zr}$ content in titanite is strongly dependent on the temperature and magma composition. We consider that the interstitial melt in Tutupaca dacitic 
magma is close to $\mathrm{SiO}_{2}$ and $\mathrm{TiO}_{2}$ saturation (70-78 wt. $\% \mathrm{SiO}_{2}$ and up to 0.52 wt. $\%$ TiO 2 ), and thus its $\mathrm{TiO}_{2}$ and $\mathrm{SiO}_{2}$ activities are almost $1 . \mathrm{Zr}$ concentrations of titanite measured by LA-ICPMS for two phenocrysts range from 488 to $588 \mathrm{ppm}$ and yield temperatures around $747 \pm 4^{\circ} \mathrm{C}$ $(\mathrm{n}=4)$. This is similar to the temperatures calculated for the low-Al amphiboles $\left(735 \pm 23^{\circ} \mathrm{C}\right)$.

\section{Figure 9}

In summary, amphiboles that record the highest temperatures display high-Al compositions and correspond to the overgrowth rims of phenocrysts or the microlites in dome rocks and the P-PDC products, as well as the amphiboles from the fine-grained mafic enclaves. In contrast, phenocrysts with low-Al compositions show globally lower temperatures, and correspond to the phenocryst cores from the lava domes and the P-PDC, as well as amphiboles in the silicic enclave. Thus, the aluminium reverse zoning patterns described in amphiboles from the second group (Fig. 5e,f) indicate an increase in temperature. These results confirm the existence of two different parageneses in Tutupaca magmas: (1) a dominant low-temperature paragenesis $\left(735 \pm 23^{\circ} \mathrm{C}\right)$, represented by the phenocryst cores of the dacites and the silicic enclave (low-Al amphibole + plagioclase + biotite + titanite + Fe-Ti oxides \pm quartz); and (2) a high-temperature paragenesis $\left(840 \pm 45^{\circ} \mathrm{C}\right)$, represented by phenocryst rims of the dacites and the mafic enclaves (high-Al amphibole + plagioclase + Fe-Ti oxides \pm clinopyroxene). 
The Al-in-hornblende geobarometer has been calibrated experimentally by several authors (i.e., Johnson and Rutherford 1989; Schmidt 1992; Mutch et al. 2016) and is widely used to estimate the crystallization pressure of calc-alkaline magmas. This formulation postulates that the $\mathrm{Al}$ content $\left(\mathrm{Al}_{\text {total }}\right)$ of amphibole is controlled by total pressure when buffered by a mineral assemblage composed of plagioclase, biotite, quartz, sanidine, titanite and Fe-Ti oxides. $\mathrm{Al}_{\text {total, }}$ however, is also sensitive to changes in temperature (edenite and Ti-Tschermack substitutions) (Poli et Schmidt 1992; Anderson et Smith 1995; Bachmann et Dungan 2002), therefore Al-inhornblende barometers can only be used within the specific temperature range at which they have been calibrated. Recently, Ridolfi et al. (2010) and Ridolfi and Renzulli (2012) proposed new calibrations to estimate temperature, pressure, $f \mathrm{O}_{2}$, melt $\mathrm{H}_{2} \mathrm{O}$, and melt major oxide compositions from amphiboles crystallized over a large compositional range (from basalts to dacites). This model, however, does not take into account the influence of temperature on $\mathrm{Al}_{\text {total }}$, and its validity has been challenged (e.g., Erdmann et al. 2015, Kiss et al. 2014; Shane and Smith 2013). Improved calibrations either take into account the influence of temperature on $\mathrm{Al}_{\text {total }}$ (Anderson and Smith 1995), or separate the influence of temperature and pressure by using only ${ }^{\mathrm{VI}} \mathrm{Al}$ for geobarometry (Médard and Le Pennec 2019, submitted).

The low-temperature $\left(735 \pm 23^{\circ} \mathrm{C}\right)$ paragenesis observed in the phenocryst cores of the Tutupaca dacites and in the silicic enclave fit the requirements for use of the traditional Al-inhornblende calibrations. Using 127 amphibole analyses from the P-PDC deposit and the youngest domes gives pressure estimates of $246 \pm 27 \mathrm{MPa}$ with the best-suited barometer (Mutch et al. 2016, calibrated at $\sim 733^{\circ} \mathrm{C}$ ). The calibrations of Anderson and Smith (1995) and Médard and Le Pennec (2019) give identical results and are all consistent within errors (Table 7). 
Pressure estimates for the silicic enclave are within error of those for the Tutupaca dacites (Table 7).

Pressure estimates for the high-temperature $\left(840 \pm 45^{\circ} \mathrm{C}\right)$ phase assemblage are more difficult to compute, because the equilibrium paragenesis used for Al-in-hornblende geobarometry is not present. Based on 72 high- $\mathrm{Al}$ amphibole compositions from the Paipatja pyroclastic density currents and the youngest domes, the temperature-corrected calibration of Anderson and Smith (1995) and the temperature-independent calibration of Médard and Le Pennec (2019) give pressure estimates within error of those for the low-temperature mineral assemblage. The calibration of Ridolfi and Renzulli (2012) specifically excluded lowtemperature data $\left(<800^{\circ} \mathrm{C}\right)$, so it cannot be used for the low-temperature amphiboles. Although it should be used with caution due to temperature effects on Al-in-amphibole barometer, results for high-temperature amphiboles are in agreement with other barometers (Table 7).

In the absence of a better barometer for the mafic enclaves (neither the calibration of Anderson and Smith (1995) nor those of Médard and Le Pennec (2019) have been calibrated for andesitic compositions), the calibration of Ridolfi and Renzulli (2012) gives pressure estimates of $254 \pm 59 \mathrm{MPa}$, within error of estimates made from the low-temperature paragenesis. All these measurements are consistent with a single depth of magma storage below Tutupaca volcano prior to the latest eruption. The most accurate determinations are those made on the low-

$\mathrm{Al}$ amphiboles, because of the better-constrained calibration for low-temperature, low-variance mineral assemblages. The average pressure from all three calibrations used on low-Al amphiboles is $233 \pm 43 \mathrm{MPa}$. Assuming lithostatic conditions and considering an upper crust bulk density of $2700 \mathrm{~kg} / \mathrm{m}^{3}$ (Kono et al. 1989), the depth of the magma storage region under 6 Tutupaca is calculated between 7 and $11 \mathrm{~km}(8.8 \pm 1.6 \mathrm{~km})$. 
Table 7

Water content

Lange et al. (2009) proposed a hygrometer based on the plagioclase-melt exchange reaction between the anorthite and albite components. More recently, Waters and Lange (2015) recalibrated this hygrometer for a temperature range of 750 to $1244{ }^{\circ} \mathrm{C}$, and pressures of up to $350 \mathrm{MPa}$ with a standard error of $0.35 \mathrm{wt} . \% \mathrm{H}_{2} \mathrm{O}$. Using our temperature estimates obtained from the amphibole-plagioclase thermometer we applied this formulation to 18 matrix glass plagioclase rim pairs from Tutupaca dacites (RD, DA and P-PDC), which yielded water contents between 3.7 to 6.4 wt.\%. Applying the same method to 11 melt inclusions in plagioclase phenocrysts from P-PDC (sample TU-12-77C) yielded similar results (3.5-4 wt.\% $\mathrm{H}_{2} \mathrm{O}$ ). Water contents measured by Raman spectroscopy in selected plagioclase-hosted melt inclusions are noticeably lower than those estimated by the Waters and Lange (2013) hygrometer. We suggest these relatively low water contents can be explained by post-entrapment water loss due to rapid diffusion and re-equilibration into the gas bubble or the host crystal during magma ascent (Chen et al. 2011; Gaetani et al. 2012; Lloyd et al. 2012). For this reason, the measured water content in MI are considered minimum values. In summary, we conclude that the pre-eruptive water content for Tutupaca dacite was at least 4 and probably 6 wt.\%, in good agreement with experimental phase equilibrium for dacitic systems.

\section{Pre-eruptive magmatic processes}


Origin of the dacitic magma reservoir

Based on the geochemical and mineralogical characteristics of Tutupaca eruptive products, we can reconstruct the magmatic processes that produced the dacitic magmas. The decrease in $\mathrm{CaO}, \mathrm{Al}_{2} \mathrm{O}_{3}$ (Fig. 4) and $\mathrm{Na}_{2} \mathrm{O}$ contents with increasing $\mathrm{SiO}_{2}$ suggest progressive crystallization of plagioclase, whereas the decrease in $\mathrm{TiO}_{2}, \mathrm{Fe}_{2} \mathrm{O}_{3} *$ and $\mathrm{P}_{2} \mathrm{O}_{5}$ with differentiation suggests fractionation of titanite, titanomagnetite, and apatite. Trace element systematics also provide some key constraints on the differentiation process. A decrease in $\mathrm{Sr}, \mathrm{Eu}$ and $\mathrm{Yb}$ suggest a significant role of plagioclase and amphibole crystallization, while the negative trends for $\mathrm{Ni}$, $\mathrm{Sc}, \mathrm{V}$ are attributed to fractionation of clinopyroxene. Thus, the dacitic Tutupaca magma was generated by a fractional crystallization process involving plagioclase, amphibole and biotite with minor amounts of clinopyroxene, titanite, apatite and Fe-Ti oxides. Although a more detailed investigation of the evolution of the Tutupaca magmas would be interesting, it is beyond the scope of this paper. We do note, however, some striking differences between the older Basal and Western Tutupaca and the younger Eastern Tutupaca dacites (Fig. 4). The recent Eastern Tutupaca samples display high $\mathrm{La} / \mathrm{Yb}$ and $\mathrm{Dy} / \mathrm{Yb}$ ratios that cannot be explained by an upper crustal fractional crystallization process. The only mineral able to produce such a REE fractionation is garnet, which is stable only at very high pressures, probably at the base of the Andean arc crust ( $c f$. Mamani et al. 2010). In addition to this fractional crystallization sequence, crustal assimilation took place during ascent of the magmas through the thick Central Andean crust of the Peruvian arc ( $c f$. Mamani et al. 2010; Samaniego et al. 2016; Rivera et al. 2017).

Recharge processes into the dacitic magma chamber 
Tutupaca samples are characterized by the occurrence of frequent and conspicuous disequilibrium textures suggesting that recharge and mixing processes occurred prior to eruption.

The main characteristics we observed in Tutupaca dacites are:

- Reverse $\left(\mathrm{An}_{27 \rightarrow 61}\right)$ and oscillatory $\left(\mathrm{An}_{32 \rightarrow 44 \rightarrow 31 \rightarrow 55}\right)$ zoning patterns in plagioclase phenocrysts (second group), which display frequent dissolution surfaces and 10-35 $\mu \mathrm{m}$ overgrowth rims. These rims are enriched in $\mathrm{CaO}\left(\mathrm{An}_{42-61}\right)$ and show relatively high $\mathrm{FeO}^{*}$ contents (0.4-0.6 wt.\%). Some plagioclase phenocrysts also display sieve or spongy textures as concentric alteration zones or rims.

- Reverse zoning and overgrowth rims on amphibole phenocrysts (described as the second group). These rims are enriched in $\mathrm{Al}\left(8-11 \mathrm{wt} . \% \mathrm{Al}_{2} \mathrm{O}_{3}\right)$ relative to the cores (6-7 wt. $\%$ $\mathrm{Al}_{2} \mathrm{O}_{3}$ ), and display high $\mathrm{MgO}$ concentrations (Mg\# 50-70). Amphibole microlites also have high- $\mathrm{Al}$ and $-\mathrm{Mg}$ contents, indicating that they grew at higher temperature and from a more mafic melt. Some amphiboles show reaction rims composed of Fe-Ti oxides, pyroxene and plagioclase (e.g. gabbroic-type alteration, de Angelis et al. 2013).

- Clinopyroxene phenocrysts also show slight reverse zoning with a core-to-rim increase in $\mathrm{MgO}$ and $\mathrm{CaO}$.

- Titanite phenocrysts display reverse and oscillatory zoning, with an increase in $\mathrm{FeO}$ * from core to rim. Some phenocrysts show reaction rims formed mainly by Fe-Ti oxides.

- Quartz xenocrysts (or antecrysts) in dacites are anhedral with rounded rims and embayments that suggest they suffered resorption process.

- Presence of scarce mafic enclaves, which is indicative of magma mingling. 
Such disequilibrium features in arc magmatic systems are generally explained as having

resulted from two different processes (Couch et al. 2001; Ruprecht and Wörner 2007): (1)

physical or compositional mixing between two magmas of different composition and physical properties; and (2) thermal or self-mixing, which means that a hot and/or mafic magma is intruded into the base of a more silicic magma chamber, resulting in heating-induced convection of the magma reservoir without physical mixing between the mafic magma and the pre-existing silica-rich magma.

In order to discriminate between these mechanisms, some researchers use the systematic variations in $\mathrm{An}$ and $\mathrm{FeO}^{*}$ (and to a lesser extent $\mathrm{MgO}$ ) contents in plagioclase (Hattori and Sato 1996; Ruprecht and Wörner 2007; Humphreys et al. 2009; Ruprecht et al. 2012). The Fe partitioning in plagioclase varies as a function of the An content, as well as of temperature, degree of oxidation and water content of the co-existing magma (Bindeman et al. 1998; Ginibre et al. 2002). However, the predicted effects of these parameters on plagioclase $\mathrm{FeO}^{*}$ content are null or relatively small (Ruprecht and Wörner 2007; Humphreys et al. 2009; Hattori and Sato 1996). Thus, an increase of $\mathrm{FeO}^{*}$ correlated with An contents reflects a change in the host magma composition. This change can be a consequence of physical mixing between a differentiated and a mafic magma. On the contrary, a mostly flat trend, characterized by a change in the An content without a $\mathrm{FeO}^{*}$ increase, mostly reflects a thermal or self-mixing process. We should stress that these are non-exclusive processes, because the heat source for self-mixing is often associated with a recharge event (Couch et al. 2001). In addition, heating may dissolve mafic phenocrysts and change the composition of the interstitial melt, thus potentially resulting in changes in plagioclase compositions. As we see in the following paragraph, magmatic systems 
display intermediate situations in which both physical (compositional) and thermal (self-) mixing occur.

In Tutupaca dacites we observe a rough positive trend between $\mathrm{An}$ and $\mathrm{FeO}$ * in plagioclase with a quite limited chemical variation ( $\mathrm{An}_{25-60}$ and 0.1-0.6 wt.\% FeO*, Fig. 10). This pattern differs from those observed at others well-studied magmatic systems such as Pinatubo (Hattori and Sato 1996), Quizapu (Ruprecht et al. 2012), Misti-Andahua (Ruprecht and Wörner 2007; Tepley et al. 2013), Soufrière Hills (Humphreys et al. 2009) or Tungurahua (Samaniego et al. 2011). For example, plagioclase compositions for the Misti-Andahua and Soufriere Hills volcanic systems show a larger chemical variation $\left(\mathrm{An}_{25-90}\right.$ and $\left.0.1-1.2 \mathrm{wt} . \% \mathrm{FeO}^{*}\right)$ and a complex behaviour, with a rough $\mathrm{An}-\mathrm{FeO}^{*}$ positive correlation below $\mathrm{An}_{60}$ and a double trend above $\mathrm{An}_{60}$ (increase in $\mathrm{An}$ at almost constant $\mathrm{FeO}^{*}$, and high $\mathrm{FeO}^{*}$ at almost constant An, Fig. 10). We thus suggest that Tutupaca plagioclases record a limited physical mixing process compared to other systems, whereas self-mixing is the dominant process, as evidenced by the scarcity of mafic enclaves.

Figure 10

Time constraints

Geochronological data reported by Samaniego et al. (2015) show identical ages for the pre-avalanche (i.e. Z-PDC) and the syn-avalanche pyroclastic events (i.e. P-PDC). This suggests that the time between these two eruptions is too small to be resolved by radiocarbon dating, arguing for a time frame of some years to a few decades. In order to confirm this hypothesis, we 
investigated the sharp core-to-rim transitions observed in plagioclase and amphibole phenocrysts (Figures $5 \mathrm{~b}, \mathrm{f}$ ). These transitions indicate that little diffusion happened between the crystallisation of the rim and the eruption. To better constrain this timing, we modelled $\mathrm{Mg}$ diffusion at the interface between the core and the rim of a selected crystal, whose major elements composition and core-rim transition is representative of the group 2 plagioclases. A simple model of diffusion in an infinite slab, starting with a step function (Lasaga 1998), diffusion coefficients from Van Orman et al. (2014), an average An content of $60 \%$, and a temperature of $835^{\circ} \mathrm{C}$, produced modelled diffusion times of 1 year (corresponding figure in Supplementary material 3), with acceptable values between a few months and 10 years. The same calculation done for $\mathrm{K}$, using the diffusion coefficients of Giletti and Shanahan (1997) also requires diffusion times shorter than 10 years, with a best fit for a diffusion time of 1 year. We propose that after injection of new magma into the base of the reservoir, the resident magma gets heated by about $100{ }^{\circ} \mathrm{C}$, and then starts cooling and recrystallizing. The modelled timescales represent the time between the beginning of the recrystallization of the magma and its emplacement at the surface, and thus provide a maximum value for the duration of the eruptive phase. Although there are large uncertainties on the measurements and models, these data would indicate that the entire eruptive phase lasted at most 10-20 years, and more likely a few years.

\section{Triggering mechanism of the eruption}

The recharge of a hot magma in a differentiated reservoir is a recurrent process in many volcanoes around the world, such as Soufriere Hills (Murphy et al. 2000; Couch et al. 2001; Rutherford and Devine 2003), Unzen (Holtz et al. 2005), Quizapu (Ruprecht and Bachmann 2010), Tungurahua (Samaniego et al. 2011, Andujar et al. 2017) and Ubinas (Rivera et al. 2014). 
This process produces re-heating of the "resident" magma, generating volatile exsolution and a subsequent pressurization of the magma reservoir (Murphy et al. 2000; Rubin et al. 2017). In addition, hot magma recharge decreases the viscosity of a differentiated magma, enabling remobilization and convection in the reservoir, and triggering explosive (i.e. Soufriere Hills, Murphy et al 2000; Couch et al. 2001) or effusive eruptions (i.e. Quizapu, Ruprecht and Bachmann 2010). At Tutupaca volcano, the dacitic reservoir is located at $7-11 \mathrm{~km}$ depth $(233 \pm$ $43 \mathrm{MPa}$ ), at an initial temperature of $735 \pm 23^{\circ} \mathrm{C}$, with a water content of at least $4-6 \mathrm{wt} . \%$. The presence of reverse zoning and overgrowth rims in plagioclase and amphibole suggests that these disequilibrium textures were produced by an increase in temperature of the magmatic system. This change in temperature was due to intrusion of a hotter magma (Fig. 11) that is represented by the scarce fine-grained mafic enclaves, which yield the highest estimated temperatures $(840 \pm$ $45^{\circ} \mathrm{C}$ ). Following the magma intrusion at the base of the dacitic reservoir, magma viscosity decreased and strong convection began, enhancing magma ascent and degassing, which could explain the lower water content measured in melt inclusions $(<4 \mathrm{wt} . \%)$. Due to the viscosity decrease and degassing, the highly crystallized dacitic magma became susceptible to eruption, magma ascent increased and as a result an enhanced dome-forming eruption begun, which was responsible for the development of the pre-avalanche dome complex. The rapid dome growth, confirmed by the short timescale (some years up to a few decades) between magmatic recharge and eruption, resulted in gravitational instability that subsequently triggered sector collapse of Tutupaca's North-East flank (Samaniego et al. 2015; Valderrama et al. 2016), generating a debris avalanche and its accompanying pyroclastic density currents. 


\section{Conclusions}

The erupted products of the Tutupaca historical eruption are chemically homogeneous (63.2-68.0 wt.\% $\left.\mathrm{SiO}_{2}\right)$, porphyritic (20-35 vol.\%) dacites with a mineral assemblage composed of plagioclase, hornblende, biotite, clinopyroxene and $\mathrm{Fe}$-Ti oxides together with some accessory minerals such as titanite, apatite and quartz. The phenocrysts from the Tutupaca dacites show common disequilibrium textures such as reverse zonation, resorption zones and overgrowth rims. These disequilibrium textures suggest a heating process triggered by the intrusion of a hot magma into a dacitic magma reservoir. Based on thermobarometric analysis, the initial temperature of the dacitic reservoir is estimated to be between 703 and $797^{\circ} \mathrm{C}$ (with an average of $735 \pm 23^{\circ} \mathrm{C}$ ) at a pressure of $230 \pm 58 \mathrm{MPa}$, corresponding to a depth range between 7 and 11 $\mathrm{km}$, and a water content between 4 and 6 wt.\%. The few fine-grained mafic enclaves (53-57 wt. $\% \mathrm{SiO}_{2}$ ), which are present in the younger dacite domes, give a higher range of temperature between 789 and $921^{\circ} \mathrm{C}\left(840 \pm 45^{\circ} \mathrm{C}\right)$. Based on these data, we propose that the recent eruption of Tutupaca was triggered by the recharge of a hotter magma into a highly crystallized dacitic magma reservoir. As a result, the resident dacitic magma was reheated and remobilized by a selfmixing process that include little, if any, physical mixing with the mafic magma. These magmatic processes induced an enhanced dome-growth phase that destabilized the NE flank of the volcano and produced the debris avalanche and its accompanying pyroclastic density currents. 
This work is part of a Peruvian-French cooperation programme carried out between the

Instituto Geológico, Minero y Metalúrgico (INGEMMET, Peru) and the Institut de Recherche pour le Développement (IRD, France). We warmly thank F. van Wyk de Vries for improvements to the English in the manuscript. We are grateful to P. Ruprecht and an anonymous reviewer for their constructive comments and J. Fierstein for the editorial handling. This is Laboratory of Excellence ClerVolc contribution $n^{\circ} \mathrm{XX}$.

\section{References}

Anderson JL, Smith DR (1995) The effects of temperature and $\mathrm{fO}_{2}$ on the Al-in-hornblende barometer. Am Mineral 80:549 - 559

Andujar J, Martel C, Pichavant M, Samaniego P, Scaillet B, Molina I (2017) Structure of the plumbing system at Tungurahua volcano, Ecuador: Insights from phase equilibrium experiments on July-August 2006 eruption products. J Petrol 58:1249-1278

Bachmann O, Dungan MA (2002) Temperature-induced Al-zoning in horblendes of the Fish Canyon magma, Colorado. Am Mineral 87:723 - 738

Belousov A (1996) Deposits of the 30 March 1956 directed blast at Bezymianny volcano. Bull Volcanol 57:649-662

Belousov A, Voight B, Belousova M (2007) Directed blasts and blast-generated pyroclastic density currents : a comparison of the Bezymianny 1956, Mount St Helens 1980, and Soufrière Hills, Montserrat 1997 eruptions and deposits. Bull Volcanol 69:701-740 
Benavente C, Zerathe S, Audin L, Hall SR, Robert X, Delgado F, Carcaillet J, ASTER Team (2017) Active transpressional tectonics in the Andean forearc of southern Peru quantified by ${ }^{10} \mathrm{Be}$ surface exposure dating of an active fault scarp. Tectonics 36 , doi:10.1002/2017TC004523.

Bindeman IN, Davis AM, Drake MJ (1998) Ion microprobe study of plagioclase- basalt partition experiments at natural concentration levels of trace elements. Geochim. Cosmochim. Acta $62: 1175-1193$

Blundy J, Holland T (1990) Calcic amphibole equilibria and a new amphibolc-plagioclase geothermometer. Contrib Mineral Petrol 104:208-224

Castro JM, Dingwell DB (2009) Rapid ascent of rhyolitic magma at Chaitén volcano, Chile, Nature 461:780-783

Castruccio A, Clavero J, Segura A, Samaniego P, Roche O, Le Pennec JL, Droguett B (2016) Eruptive parameters and dynamics of the April 2015 sub-Plinian eruptions of Calbuco volcano (southern Chile). Bull Volcanol 78:62

Chen Y, Provost A, Schiano P, Cluzel N (2011) The rate of water loss from olivine-hosted melt inclusions. Contrib Mineral Petrol 162: 625-636

Cotten J, Le Dez A, Bau M, Caroff M, Maury RC, Dulski P, Fourcade S, Bohn M, Brousse R (1995) Origin of anomalous rare-earth element and Yttrium enrichments in subaerial exposed basalts: evidence from French Polynesia. Chem Geol 119:115-138

Couch S, Sparks RSJ, Carroll MR (2001) Mineral disequilibrium in lavas explained by convective self-mixing in open magma chambers. Nature 41:1037-1039 
De Angelis SH, Larsen J, Coombs M (2013) Pre-eruptive magmatic conditions at Augustine volcano, Alaska, 2006: Evidence from amphibole geochemistry and textures. J Petrol 54:1939-1961

Erdmann S, Martel C, Pichavant M, Kushnir A (2014) Amphibole as an archivist of magmatic crystallization conditions: problems, potential, and implications for inferring magma storage prior to the paroxysmal 2010 eruption of Mount Merapi, Indonesia. Contrib Mineral Petrol $167: 1016$

Fidel L, Zavala B (2001) Mapa preliminar de amenaza volcánica del volcán Tutupaca. Boletín 24, Serie C: Geodinámica e Ingeniería Geológica, INGEMMET, 109 p

Gaetani GA, O'Leary JA, Shimizu N, Bucholv CE, Newville M (2012) Rapid re-equilibration of $\mathrm{H}_{2} \mathrm{O}$ and oxygen fugacity in olivine-hosted inclusions. Geology 40:915-918

Giletti BJ, Shanahan TM (1997) Alkali diffusion in plagioclase feldspar. Chemical Geology $139: 3-20$

Ginibre C, Wörner G, Kronz A (2002) Minor- and trace-element zoning in plagioclase: implications for magma chamber processes at Parinacota Volcano, northern Chile. Contributions to Mineralogy and Petrology 143:300-315

Hattori K, Sato H. (1996) Magma evolution recorded in plagioclase zoning in 1991 Pinatubo eruption products. American Mineralogist 81: 982-994

Hayden LA, Watson EB, Wark DA (2008) A thermobarometer for sphene (titanite). Contrib Mineral Petrol 155:529-540

Hoblitt RP, Miller CD, Vallance JW (1981) Origin and stratigraphy of the deposit produced by 
the May 18 directed blast. In: Lipman PW, Mullineaux DR (eds) The 1980 eruptions of Mount St. Helens, Washington. USGS Prof Paper 1250:401-419

Holland T, Blundy J (1994) Non-ideal interactions in calcic amphiboles and their bearing on amphibole-plagioclase thermometry. Contrib Mineral Petrol 116:433-447

Holtz F, Sato H, Lewis J, Behrens H, Nakada S (2005) Experimental Petrology of the 1991 1995 Unzen Dacite, Japan . Part I : Phase Relations, Phase Composition and Pre-eruptive Conditions. J Petrol 46:319-337

Humphreys MCS, Christopher T, Hards V (2009) Microlite transfer by disaggregation of mafic inclusions following magma mixing at Soufrière Hills volcano Montserrat. Contrib. Mineral. Petrol. 157:609-624. doi:10.1007/s00410-008-0356-3

Johnson MC, Rutherford MJ (1989) Experimental calibration of the aluminum-in-hornblende geobarometer with application to Long Valley caldera (California) volcanic rocks. Geology $17: 837-841$

Kiss B, Harangi S, Ntaflos T, Mason PRD, Pál-Molnár E (2014) Amphibole perspective to unravel pre-eruptive processes and conditions in volcanic plumbing systems beneath intermediate arc volcanoes: a case study from Ciomadul volcano (SE Carpathians). Contrib Mineral Petrol 167:986

Kono M, Fukao Y, Yamamoto A (1989) Mountain building in the Central Andes. J Geophys Res 94:3891-3905

Lange R, Frey H, Hector J (2009) A thermodynamic model for the plagioclase-liquid hygrometer/thermometer. Am Mineral 94:494-506 
Lara LE, Naranjo JA, Moreno H (2004) Rhyodacitic fissure eruption in Southern Andes (Cordón Caulle; 40.5 $\mathrm{S}$ ) after the 1960 (Mw:9.5) Chilean earthquake: a structural interpretation. J Volcanol Geotherm Res 138:127-138

Lasaga AC (1998). Kinetic theory in the earth sciences. Princetown series in geochemistry. Princeton University Press, Princeton, N.J.

Leake BE, Woolley AR, Arps CES, Birch WD, Gilbert MC, Grice JD, Hawthorne FC, Kato A, Kisch HJ, Krivovichev VG, Linthout K, Laird J, Mandarino JA, Maresch WV, Nickel EH, Rock NMS, Schumacher JC, Smith DC, Stephenson CN, Ungaretti L, Whittaker EJW, Youzhi G (1997) Nomenclature of amphiboles: report of the Subcommittee on Amphiboles of the International Mineralogical Association, commission on new minerals and minerals' names. Am Mineral 82:1019-1037

Lloyd AS, Plank T, Ruprecht P, Hauri EH, Rose W (2012) Volatile loss from melt inclusions in pyroclasts of differing sizes. Contrib Mineral Petrol 165:129-153

Mamani M, Wörner G, Sempere T (2010) Geochemical variation in igneous rocks of the Central Andean orocline $\left(13^{\circ} \mathrm{S}\right.$ to $\left.18^{\circ} \mathrm{S}\right)$ : tracing crustal thickening and magmas generation through time and space. Geological Society of America Bulletin 97:241-254

Mariño J, Samaniego P, Manrique N, Valderrama P, Macedo L (2019) Geología y mapa del Complejo Volcánico Tutupaca. INGEMMET, Boletín, Serie C: Geodinámica e Ingeniería Geológica, 66, 165 p., 2 mapas.

Médard E, Le Pennec JL, Francomme JE, Temel A, Nauret F (2013) Reconstructing the magma feeding system of the Cappadocian ignimbrites (Turkey) through amphibole thermobarometry. Goldschmidt conference, Florence, Italy 
Médard E, Le Pennec JL (2019) Petrologic imaging of the magma chambers that feed supereruptions. Submitted

Morimoto N, Fabries J, Ferguson AK, Ginzburg IV, Ross M, Seifert FA, Zussman J (1988) Nomenclature of pyroxenes. Am Mineral 73:1123-1133

Murphy MD, Sparks RSJ, Barclay J, Carroll MR, Brewer TS, Gene DE (2000) Remobilization of Andesite Magma by Intrusion of Mafic Magma at the Soufriere Hills Volcano, Montserrat, West Indies. J Petrol 41: 21-42

Mutch EJF, Blundy JD, Tattitch BC, Cooper FJ, Brooker RA (2016) An experimental study of amphibole stability in low-pressure granitic magmas and a revised Al-in-hornblende geobarometer. Contrib Mineral Petrol 171:85

Pallister JS, Hoblitt RP, Reyes AG (1992) A basalt trigger for the 1991 eruptions of Pinatubo volcano? Nature 356:426-428

Peccerillo P, Taylor SR (1976) Geochemistry of Eocene calc-alkaline volcanic rocks from the Kastamonu area, northern Turkey. Contrib Mineral Petrol 58:63-81

Poli S, Schmidt MW (1992) A comment on Calcic amphibole equilibria and a new amphiboleplagioclase thermometrer by JD Blundy and TJB Holland. Contrib Mineral Petrol 104:208224

Prouteau G, Scaillet B (2003) Experimental constraints on the origin of the 1991 Pinatubo dacite. J Petrol 44:2203-2241

Ridolfi F, Renzulli A, Puerini M (2010) Stability and chemical equilibrium of amphibole in calcalkaline magmas: an overview, new thermobarometric formulations and application to 
subduc- tion-related volcanoes. Contrib Mineral Petrol 160:45-66

Ridolfi F, Renzulli A (2012) Calcic amphiboles in calc-alkaline and alkaline magmas: thermobarometric and chemometric empirical equations valid up to $1130 \mathrm{oC}$ and $2.2 \mathrm{GPa}$. Contrib Mineral Petrol 163:877-895

Rivera M, Thouret JC, Samaniego P, Le Pennec JL (2014) The 2006-2009 activity of Ubinas volcano (Peru): petrology of the 2006 eruptive products and insights into genesis of andesite magmas, magma recharge and plumbing system. J Volcanol Geotherm Res 270:122-141

Rivera M, Martin H, Le Pennec JL, Thouret JC, Gourgaud A, Gerbe MC (2017) Petrogeochemical constraints on the source and evolution of magmas at El Misti volcano (Peru). Lithos 268-271:240-259

Rubin AE, Cooper KM, Till CB, Kent AJR, Costa F, Bose M, Gravley D, Deering C, Cole J (2017) Rapid cooling and cold storage in a silicic magma reservoir recorded in individual crystals. Science $356: 1154-1156$

Ruprecht P, Bachmann O (2010) Pre-eruptive reheating during magma mixing at Quizapu volcano and the implications for the explosiveness of silicic arc volcanoes. Geology 38:919-922

Ruprecht P, Wörner G (2007) Variable regimes in magma systems documented in plagioclase zoning patterns: El Misti stratovolcano and Andahua monogenetic cones. J Volcanol Geotherm Res 165:142-162

Ruprecht P, Bergantz G, Cooper K, Hildreth W (2012) The crustal magma storage system of Volcán Quizapu, Chile, and the effects of magma mixing on magma diversity. Journal of 
Petrology 53: 801- 840. doi:10.1093/petrology/egs002.

Rutherford MJ, Devine JD (1988) The May 18, 1980, Eruption of Mount St. Helens 3. Stability and chemistry of amphibole in the magma chamber. J Geophys Res 93:11949-11959

Rutherford MJ, Hill P (1993) Magma ascent rates from amphibole breakdown: An experimental study applied to the 1980-1986 Mount St. Helens eruptions. Journal of Geophysical Research 981. 10.1029/93JB01613

Rutherford MJ, Devine JD (2003) Magmatic conditions and magma ascent as indicated by hornblende phase equilibria and reactions in the 1995-2002 Soufrière Hills magma. J Petrol $44: 1433-1454$

Samaniego P, Le Pennec JL, Robin C, Hidalgo S (2011) Petrological analysis of the pre-eruptive magmatic process prior to the 2006 explosive eruptions at Tungurahua volcano (Ecuador). $\mathbf{J}$ Volcanol Geotherm Res 199:69-84

Samaniego P, Valderrama P, Mariño J, van Wyk de Vries B, Roche O, Manrique N, Chédeville C, Liorzou C, Fidel L, Malnati J (2015) The historical (218 $\pm 14 \mathrm{aBP}$ ) explosive eruption of Tutupaca volcano (Southern Peru). Bull Volcanol 77:51

Samaniego P, Rivera M, Mariño J, Guillou H, Liorzou C, Zerathe S, Delgado R, Valderrama P, Scao V (2016) The eruptive chronology of the Ampato-Sabancaya volcanic complex (Southern Peru). J Volcanol Geoth Res 323:110-128

Scaillet B, Evans BW (1999) The 15 June 1991 Eruption of Mount Pinatubo: I. Phase equilibria and pre-eruption P-T- $f \mathrm{O}_{2}-f \mathrm{H}_{2} \mathrm{O}$ conditions of the dacite magma. J Petrol 40:381-411

Schiavi F, Bolfan-Casanova N, Withers AC, Médard E, Laumonier M, Laporte D, Flaherty T, 
Gomez-Ulla A (2018) Water quantification in silicate glasses by Raman spectroscopy: correcting for the effects of confocality, density and ferric iron. Chemical Geology 483:312331

Schmidt MW (1992) Amphibole composition in tonalite as a function of pressure: an experimental calibration of the Al-in-hornblende barometer. Contrib Mineral Petrol 110:304-310

Shane P, Smith VC (2013) Using amphibole crystals to reconstruct magma storage temperatures and pressures for the post-caldera collapse volcanism at Okataina volcano. Lithos 156-159: $159-170$

Stix J, Torres R, Narváez L, Cortés G, Raigosa J, Gómez D, Castonguay R (1997) A model of vulcanian eruptions at Galeras volcano, Colombia. J Volcanol Geotherm Res 77:285-303

Sun SS, McDonough WF (1989) Chemical and isotopic systematics of oceanic basalts: implications for mantle composition and processes. In: Saunders AD, Norry MJ (eds) Magmatism in the ocean basins. Special Publication 42, Geological Society, London, pp $313-345$

Tepley FJ, de Silva S, Salas G (2013) Magma dynamics and petrological evolution leading to the VEI 52000 BP eruption of El Misti volcano, Southern Peru. J. Petrol 54:2033-2065

Thouret J, Wörner G, Gunnell Y, Singer B, Zhang X, Souriot T (2007) Geochronologic and stratigraphic constraints on canyon incision and Miocene uplift of the Central Andes in Peru. Earth and Planetary Science Letters 263:151-166.

Valderrama P, Roche O, Samaniego P, van Wyk de Vries B, Bernard K, Mariño J (2016) 
2

Dynamic implications of ridges on a debris avalanche deposit at Tutupaca volcano (southern Peru). Bull Volcanol 78:14

Valdivia JG (1847) Fragmentos para la historia de Arequipa. Folletín de "El Deber", Arequipa, $109-111 \mathrm{p}$

Van Orman JA, Cherniak DJ, Kita NT (2014) Magnesium diffusion in plagioclase: Dependence on composition, and implications for thermal resetting of the $26 \mathrm{Al}-26 \mathrm{Mg}$ early solar system chronometer. Earth and Planetary Science Letters 385:79-88

Voight B, Komorowski JC, Norton GE, Belousov AB, Belousova M, Boudon G, Francis PW, Franz W, Heinrich P, Sparks RSJ, Young SR (2002) The 1997 Boxing Day Sector Collapse and Debris Avalanche, Soufriere Hills Volcano, Montserrat, W.I. In: Druitt T, Kokelaar BP (eds), The eruption of Soufrière Hills Volcano, Montserrat, from 1995 to 1999. Mem Geol Soc London 21:363-407

Waters LE, Lange RA (2015) An updated calibration of the plagioclase-liquid hygrometerthermometer applicable to basalts through rhyolites. Am Mineral 100:2172-2184

Zamácola y Jaúregui JD (1804) Apuntes para la historia de Arequipa. Imp. De La BolsaGuañamarca, N. 49. 1888

Zhang X, Liu B, Wang J, Zhang Z, Shi K, Wu S (2014) Adobe photoshop quantification (PSQ) rather than point-counting: A rapid and precise method for quantifying rock textural data and porosities. Computers and Geosciences 69:62-71

Figure Captions 
Fig. 1 a Location of the Tutupaca Volcanic Complex (TVC) in the Peruvian volcanic arc. b Geological map of the Eastern Tutupaca edifice (modified after Samaniego et al. 2015). RD Recent domes, P-PDC - Paipatja pyroclastic density currents deposits, DA - Debris avalanche deposits, Z-PDC - Zuripujo pyroclastic density current deposits. Regional faults come from Mariño et al. (2019)

Fig. 2 a View southwest of Tutupaca with the DA and P-PDC deposits (Photo by P. Valderrama). Photos of the different eruptive products, b large dome block in the DA deposits, note the person for scale, $\mathbf{c}-\mathbf{d}$ breadcrust bombs in the P-PDC deposits

Fig. 3 a Microphotograph of a block in the debris avalanche deposit (TU-12-37) showing a large plagioclase phenocryst (first group as described in text) and a small amphibole phenocryst (first group) in a microlite-rich matrix. b Microphotograph of a recent dome sample (Dome V, TU-1270) showing a porphyritic texture with a partially vesiculated, microlite-rich matrix and amphibole (amph), plagioclase (pl) and titanite (tnt) phenocrysts. Note the thin overgrowth rim of the plagioclase crystal (second group described in text). c-d Amphibole phenenocrysts (Dome I, TU-12-42 and Dome V, TU-12-70) of the first (c) and second (d) groups. e Clinopyroxene phenocrysts in a P-PDC dacite sample (TU-12-77C). f Anhedral quartz (qtz) crystal in a P-PDC dacite sample (TU-12-77C). g Mafic enclave hosted in a dacite (TU-14-01). h Silicic enclave showing subhedral quartz, and inter-growing of amphibole and plagioclase into a crystallized plagioclase-rich matrix (TU-14-08). All images are in polarized light 
Fig. 4 Major (a-d) and trace element concentrations (e-j) and ratios (k-l) for eruptive products of the Recent (Eastern) Tutupaca, plotted versus $\mathrm{SiO}_{2}$ as a differentiation index. Subdivision in $\mathrm{K}_{2} \mathrm{O}$ vs. $\mathrm{SiO}_{2}$ diagram is from Peccerillo and Taylor (1976). B - basalt, BA - basaltic andesite, A andesite, $\mathrm{D}$ - dacite, $\mathrm{MK}$ - medium potassium, $\mathrm{KH}$ - high potassium. $\mathrm{RD}$ - Recent domes, PPDC - Paipatja pyroclastic density currents deposits, DA - Debris avalanche deposits, Z-PDC Zuripujo pyroclastic density currents deposits, ME - Mafic enclaves, SE - Silicic enclaves. Grey fields represent data from Western and Basal Tutupaca (65 unpublished data, Mariño et al. 2019), with individual data points plotted only in a for clarity; Western and Basal Tutucapa (dark and light grey diamonds, respectively)

Fig. 5 a Plagioclase phenocryst with an overgrowth rim corresponding to the second group (dome VII, sample TU-12-14). b Rim-core-rim profile showing an increase in Anorthite and $\mathrm{FeO}^{*}$ in the overgrowth rim. c Plagioclase phenocryst with oscillatory zoning correspond to the first group (P-PDC, TU-12-06A). d Core-rim profile showing a decrease Anorthite and FeO* in the rim. e Amphibole phenocryst with an overgrowth rim, corresponding to the second group (dome I, sample TU-12-42). f Profile of the amphibole showing an increase in ${ }^{\mathrm{IV}} \mathrm{Al}$ and $\mathrm{Mg \#}$ towards the rim. g Zoned amphibole (dome I, sample TU-12-42). h Profile of the amphibole showing a decrease in ${ }^{\mathrm{IV}} \mathrm{Al}$ and an increase $\mathrm{Mg} \#$ towards the rim. White dots in a, c, e and $\mathbf{g}$ correspond to analysis points 
Fig. 6 Rare earth element diagrams normalized to chondrites (Sun and McDonough 1989) for selected minerals. a High-Al amphibole, b Low-Al amphibole c plagioclase, d clinopyroxene e titanite

Fig. 7 a $\mathrm{K}_{2} \mathrm{O}$ (wt.\%), b $\mathrm{CaO}$ (wt.\%), $\mathrm{Al}_{2} \mathrm{O}_{3}$ (wt.\%) and d $\mathrm{MgO}$ (wt.\%) compositions plotted against $\mathrm{SiO}_{2}$ (wt.\%) for interstitial matrix glasses (MG) and melt inclusions (MI). Subdivision in $\mathrm{K}_{2} \mathrm{O}$ vs. $\mathrm{SiO}_{2}$ diagram is from Peccerillo and Taylor (1976). Same symbols and fields as in Fig. 4. Note that MG and MI data roughly fall in the high-silica extension of the whole-rock Tutupaca magmatic series

Fig. 8 a Na+K vs. ${ }^{I V} \mathrm{Al}, \mathbf{b}^{\mathrm{VI}} \mathrm{Al} v s .{ }^{\mathrm{IV}} \mathrm{Al}$, and $\mathbf{c} \mathrm{Mg \#} v s$. Si diagrams for Tutupaca amphiboles (after Poli and Schmidt 1992). C - Core, R - Rim, M - Microlite, a.p.f.u. - atoms per formula unit. d Amphibole microlite with an overgrowth rim, corresponding to the second group (sample TU12-70). TR, tremolite; ED, edenite; PG, pargasite; TS, tschermakite; HB, hornblende. Vectors represent the exchange reactions discussed in the text Symbols correspond to rim analyses. Note that rims exhibit a coupled increase of ${ }^{\mathrm{IV}} \mathrm{Al}$ and $\mathrm{Mg \#}$ with temperature 
Fig. 10 Diagram of a FeO* (wt.\%) and b $\mathrm{MgO}$ (wt.\%) against An (mol.\%) for plagioclase. Same symbols as Fig. 8. Fields for Soufrière Hills (Humphreys et al. 2009) and Misti-Andahua volcanoes (Ruprecht and Wörner 2007, Tepley et al. 2013) for comparison. We observe a rough positive trend in $\mathrm{FeO}^{*}$ vs. An, whereas some scattering is observed in $\mathrm{MgO}$ vs. An. Note that Tutupaca plagioclases display a limited chemical variation as compared with other well-studied volcanic systems plotted here

\section{.}

Fig. 11 Schematic conceptualization of the magmatic plumbing system below Tutupaca a, before and, b, after hot and/or mafic magma recharge into the base of the dacitic reservoir. Magma recharge triggers a thermal or "self-mixing" process that results in heating-induced convection of the magma reservoir without physical mixing between the mafic magma and the pre-existing dacitic magma. "Self-mixing" is the repercussion on the silicic magma of the close and sudden contact with hotter and more mafic magma. The orange colour of the reservoir represents the magma before recharge; the red colour the recharged magma, and the brown colour represents the magma after the recharge event

\section{.}

\section{Supplementary material 1. Description of the analytical methods}

Supplementary Material 2. Trace elements composition in selected minerals from Tutupaca dacites. PL - plagioclase, AMPH - amphibole, TTN - titanite, CPX - clinopyroxene. C - core, I - interior, R - rim 
907 Supplementary Material 3. a XAn and minor elements profiles through the sharp interface between the outermost An-rich zone and the next An-poor inner zone of a plagioclase phenocryst 909 in a pumice from the P-PDC deposit. The $\sim 10 \mu \mathrm{m}$ outer zone records the last magmatic event that affected the Tutupaca system, but more complex zoning is also present in the inner parts of

911 the crystal (see Fig. 5). b Magnification of the MgO profile (Profile 1), together with another

$912 \mathrm{MgO}$ profile taken in the same crystal. Diffusion modelling suggests a timescale of less than 10

913 years. Error bars are 2 sigma analytical errors from the electron microprobe 


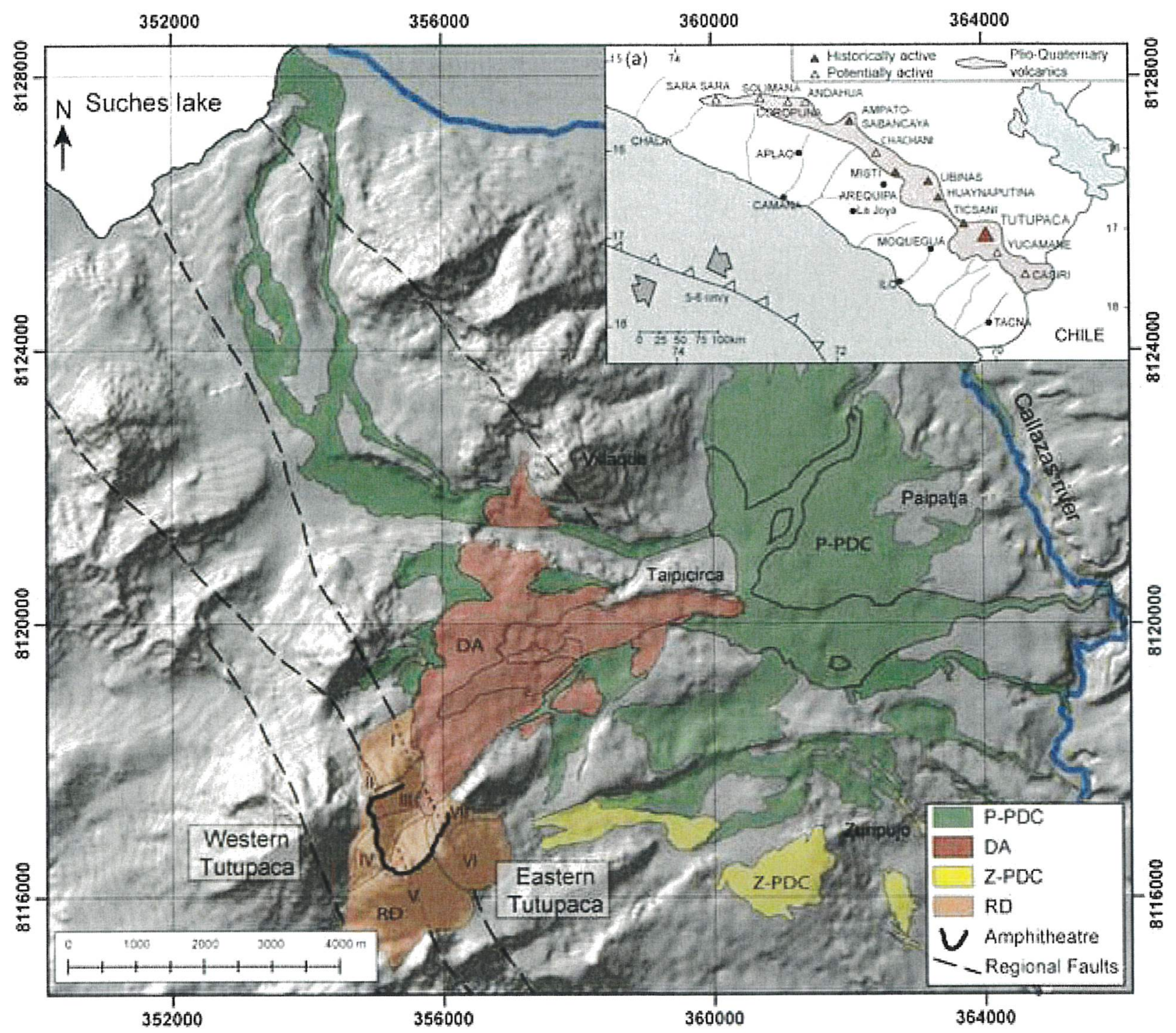



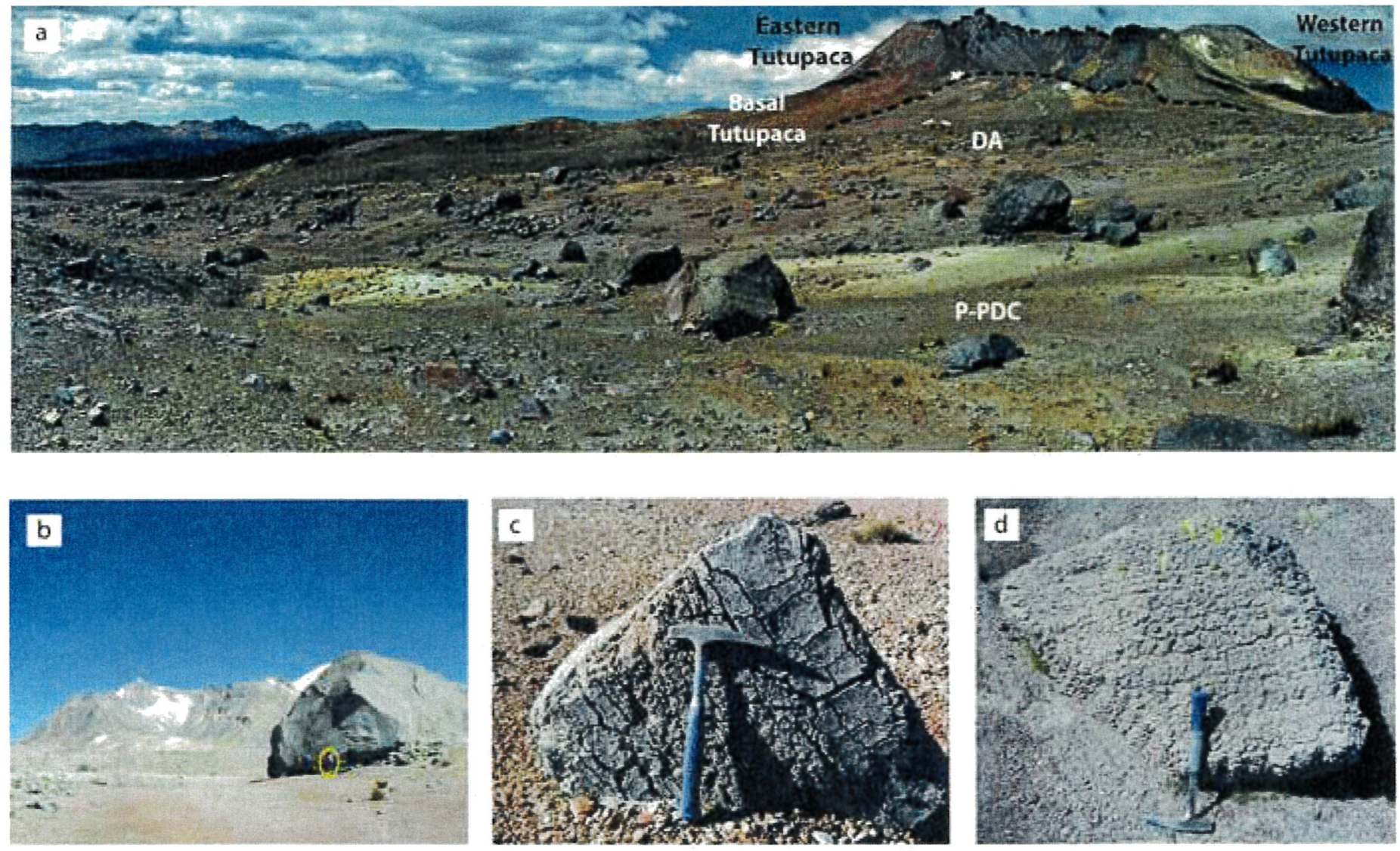


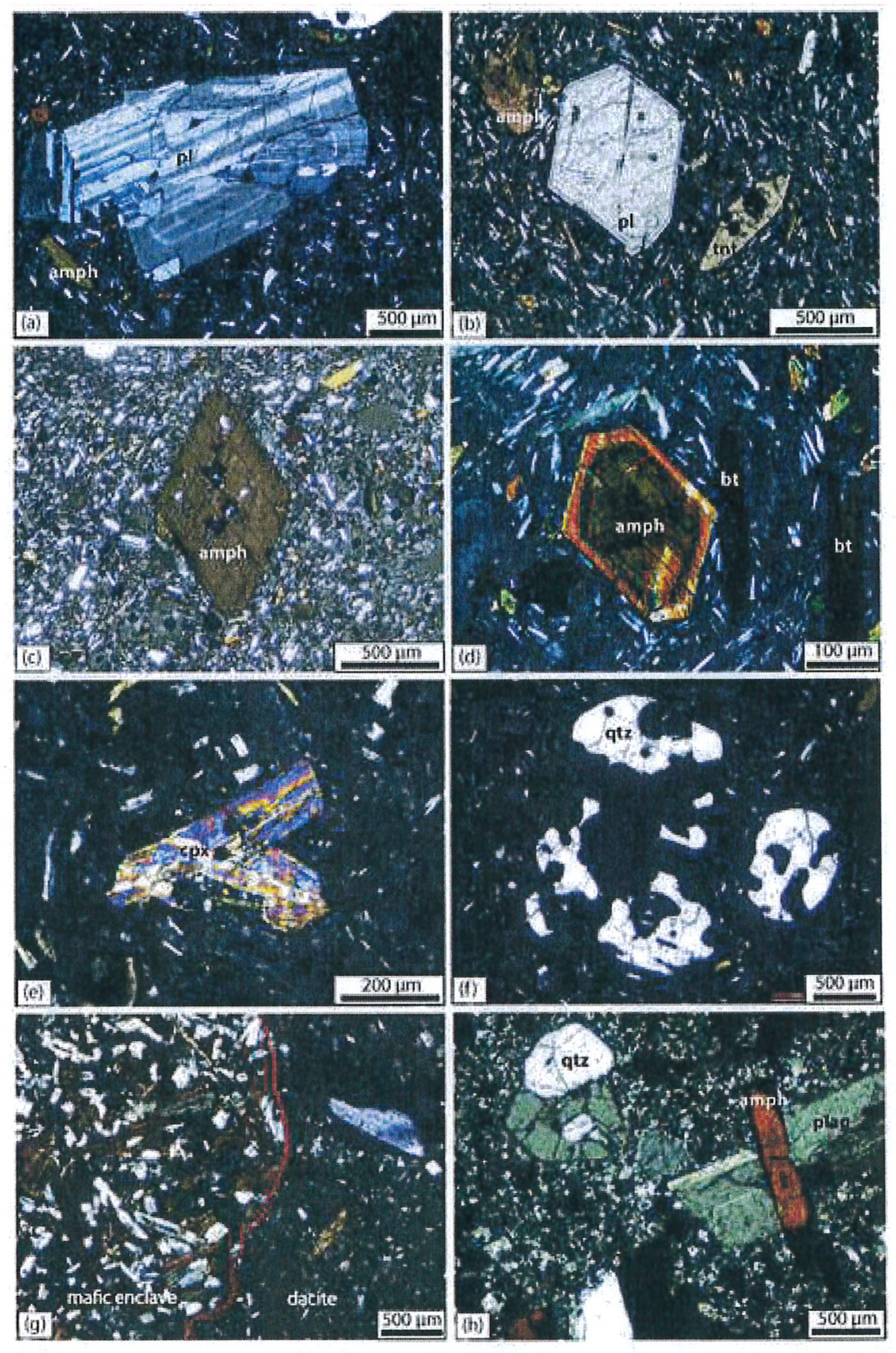



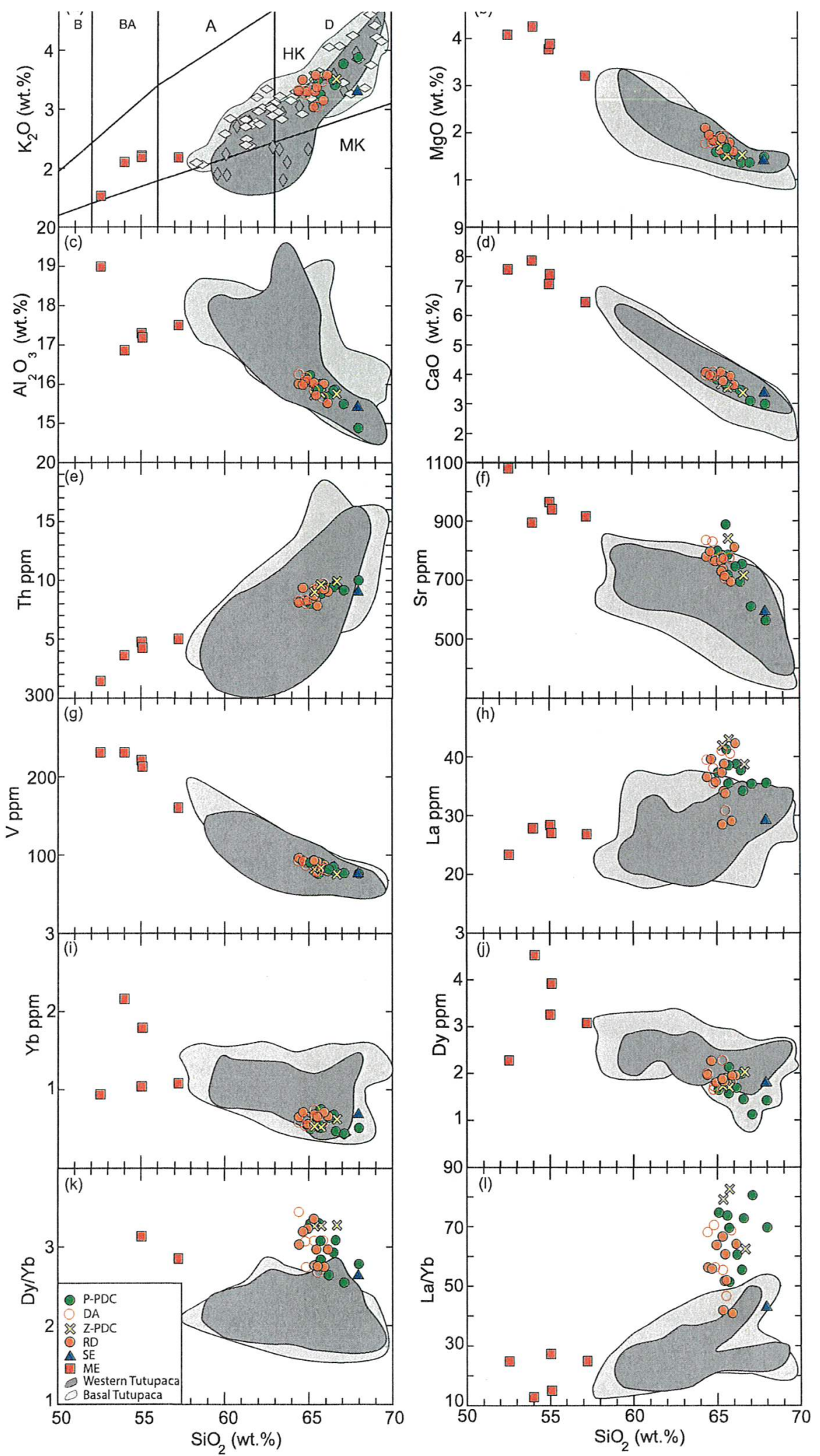

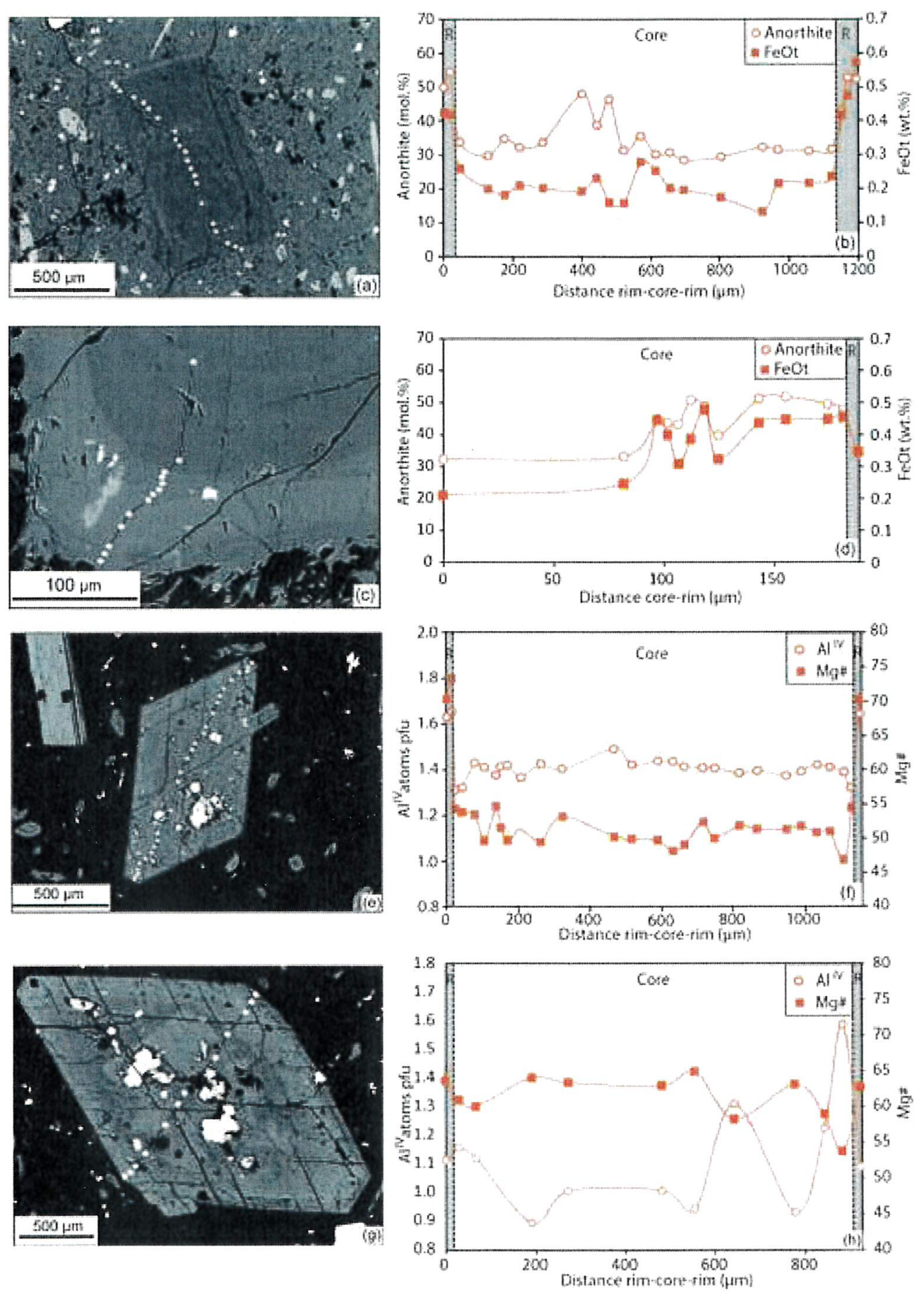

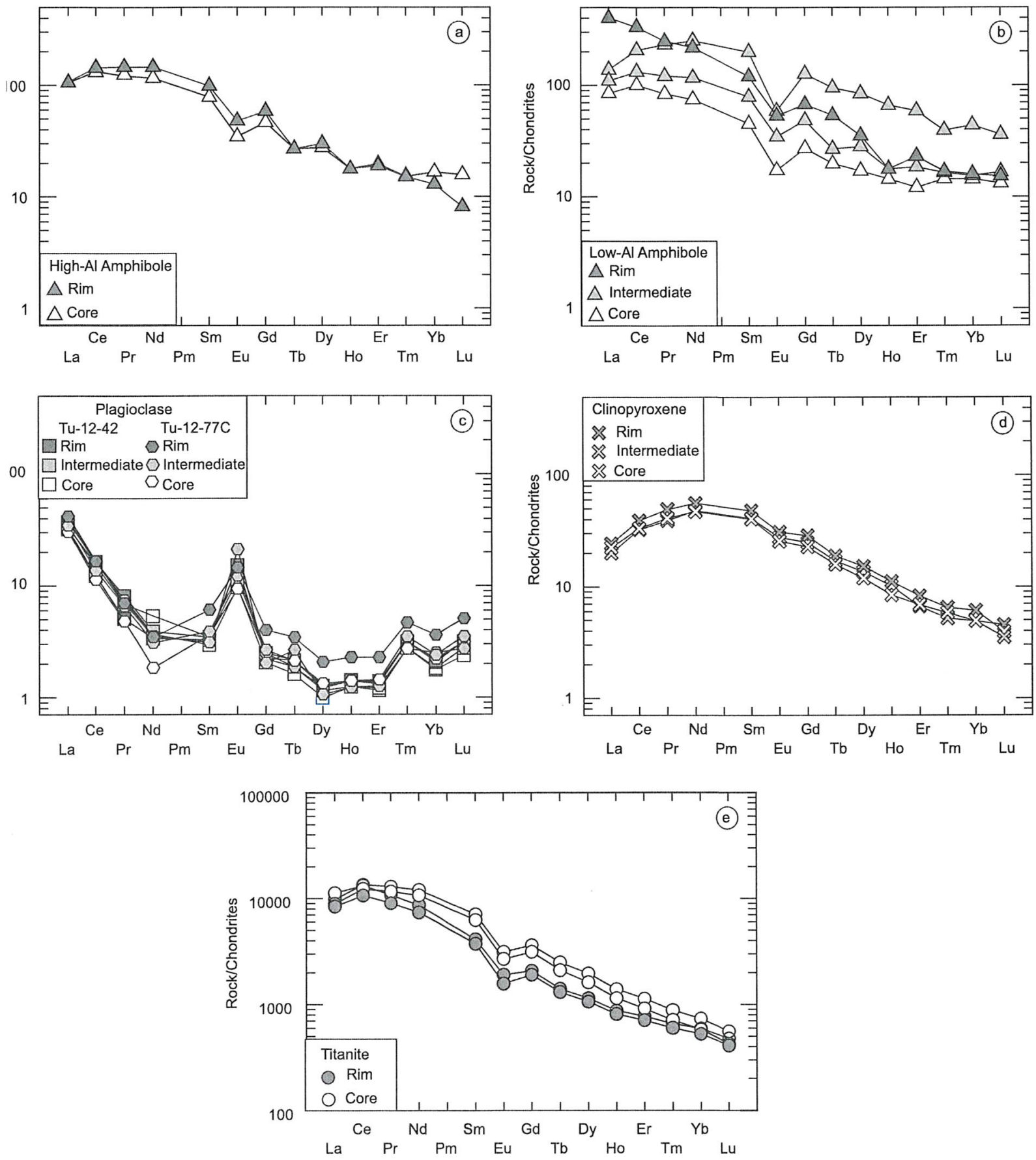

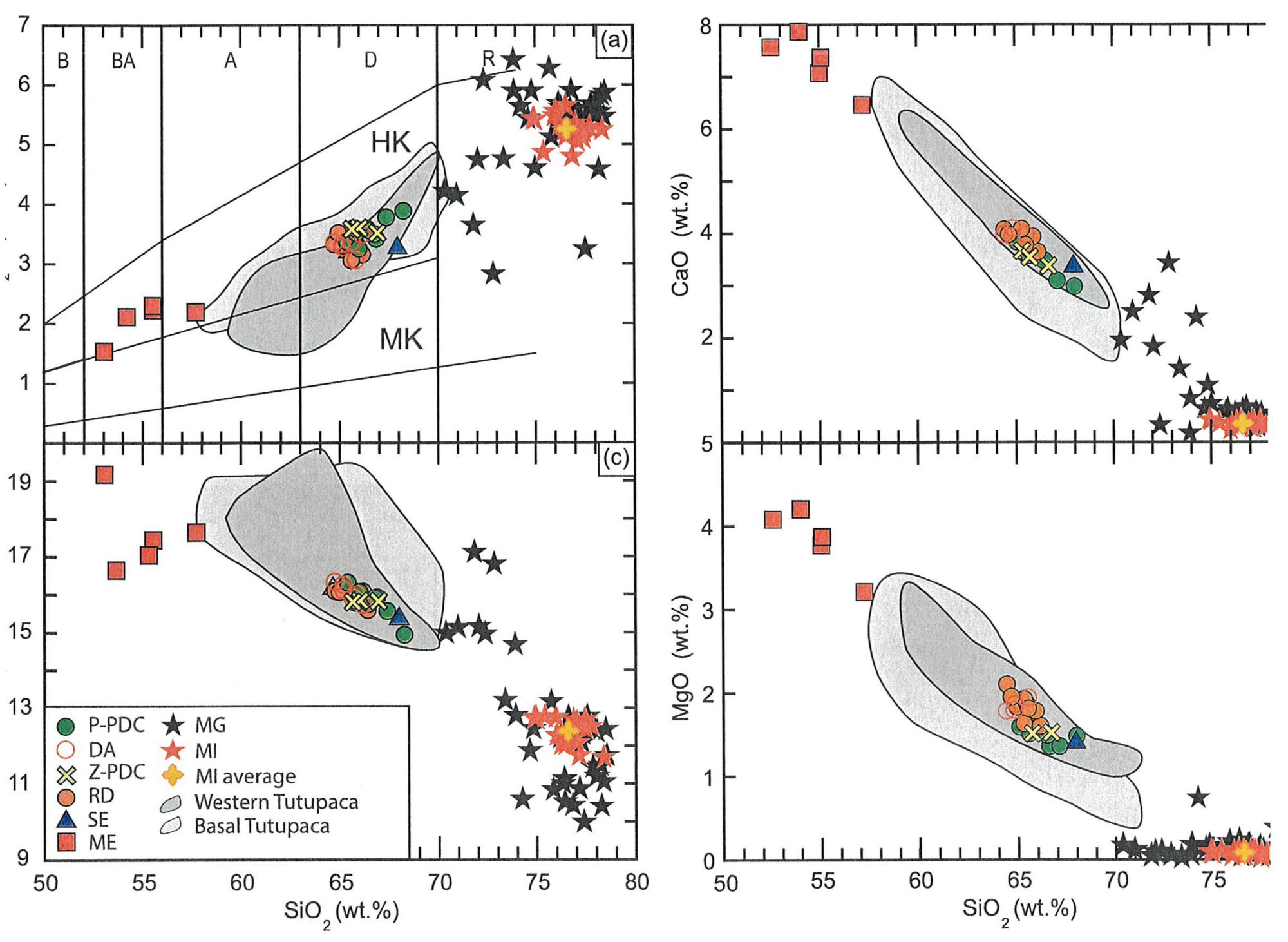

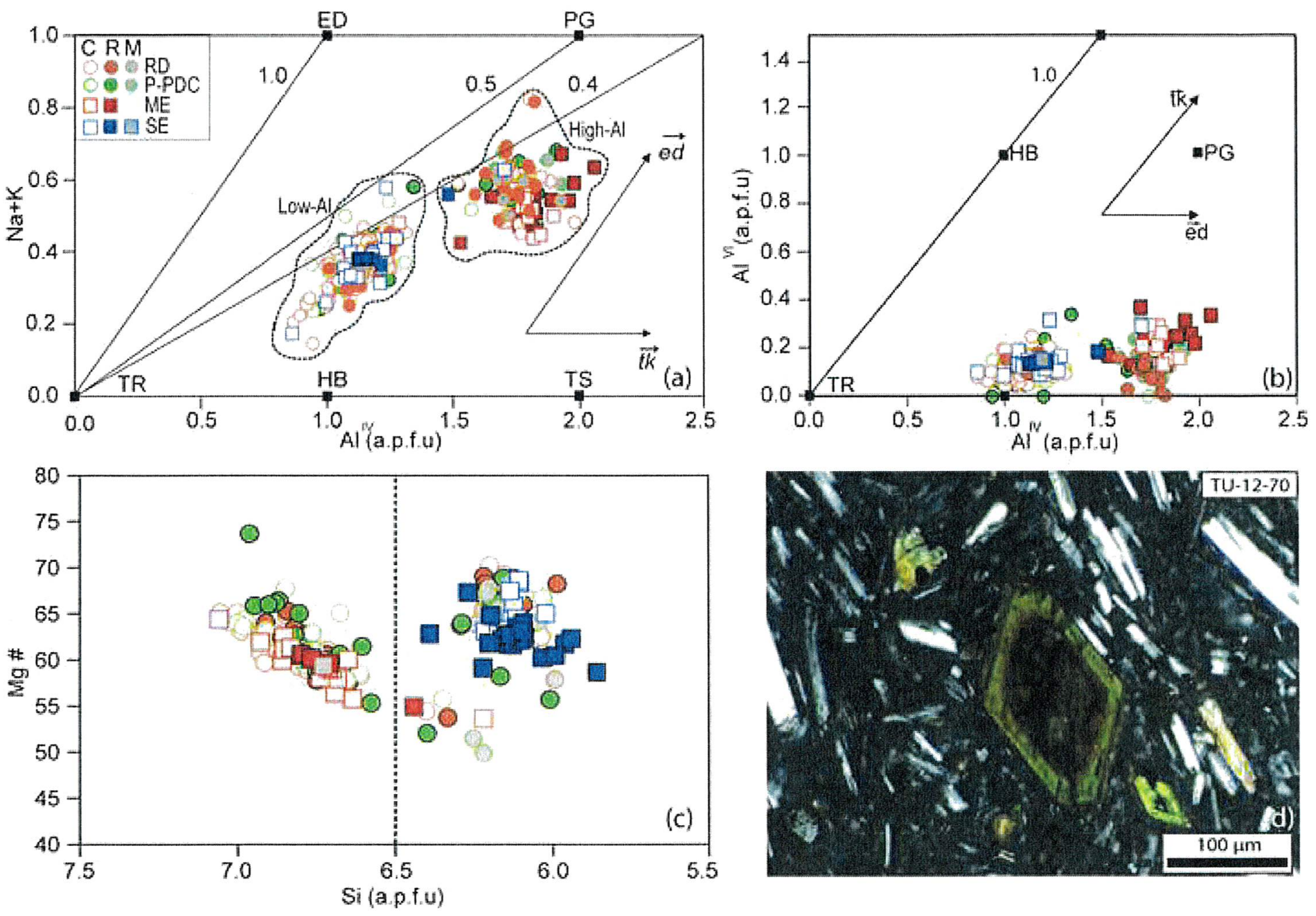

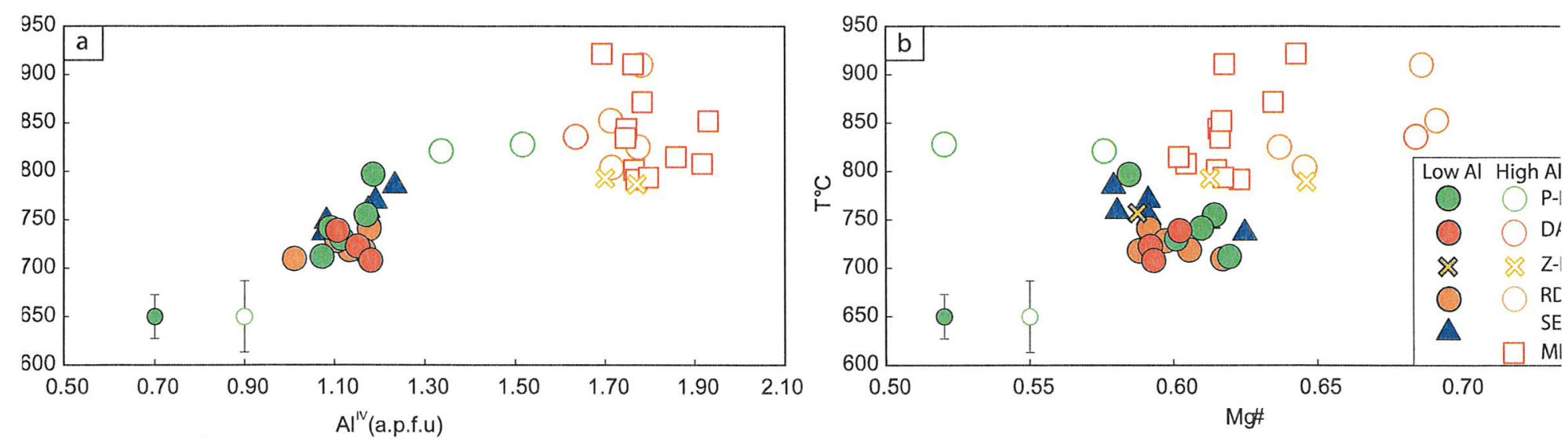


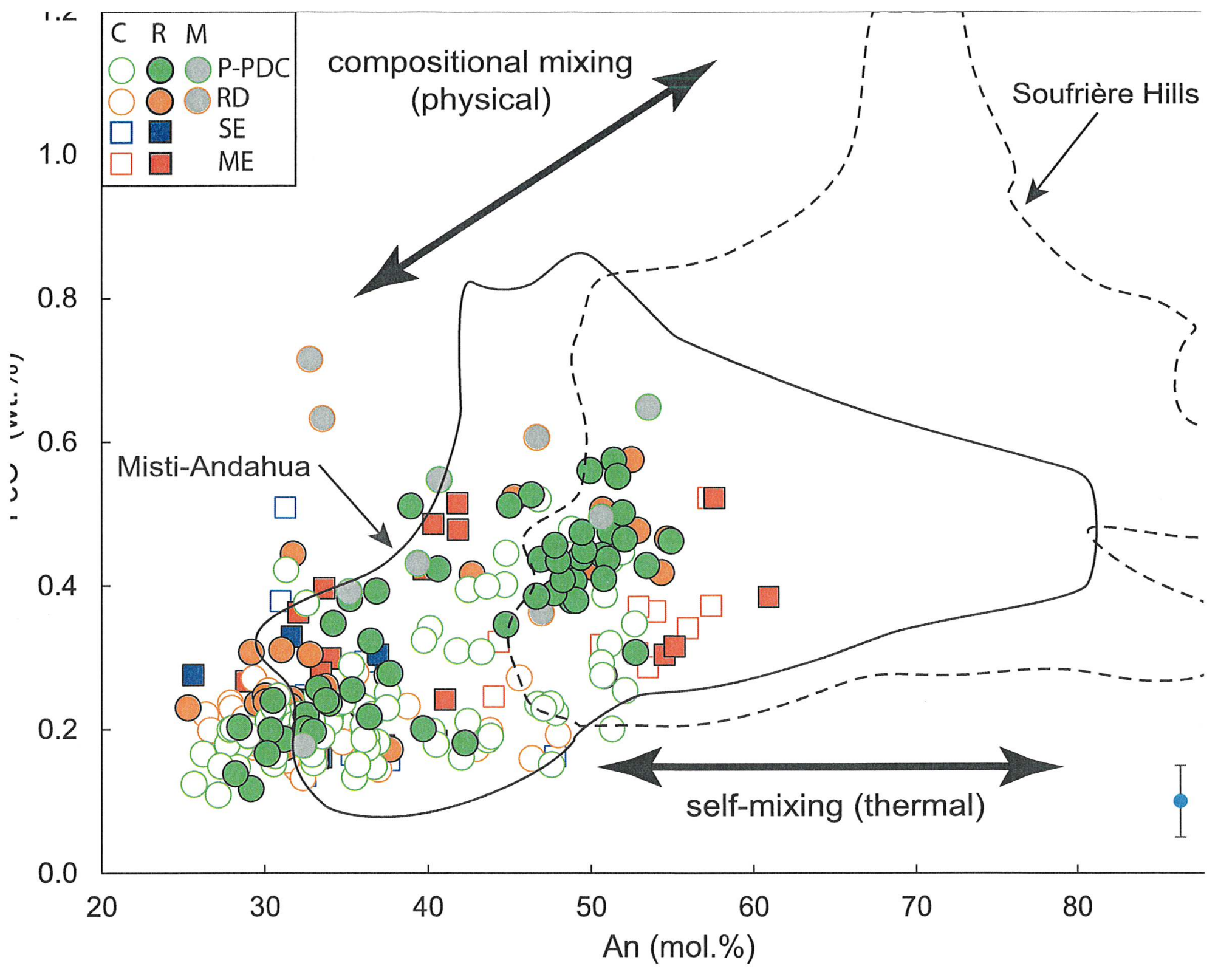


V

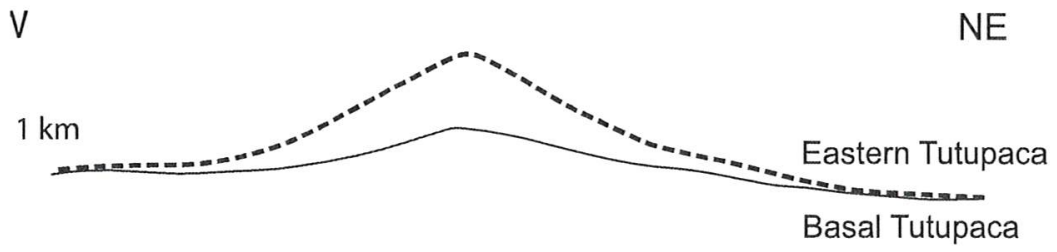

3

5

Dacitic reservoir before recharge

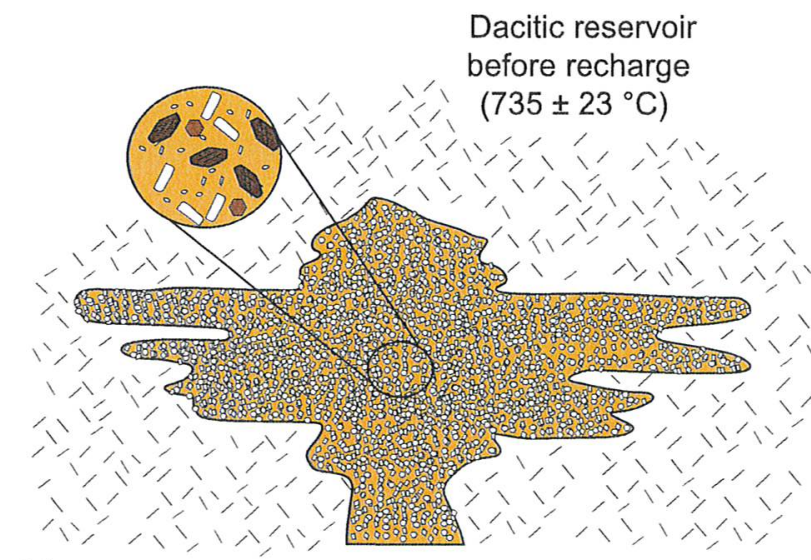

$1 \mathrm{~km}$

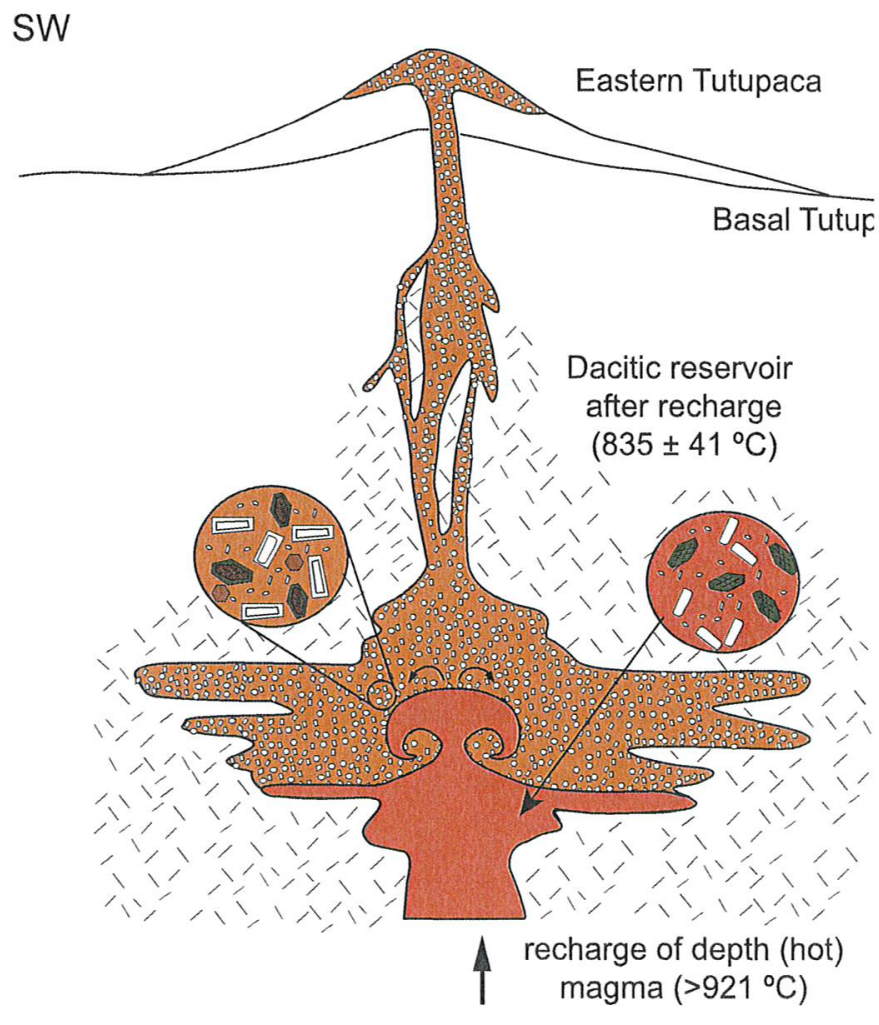




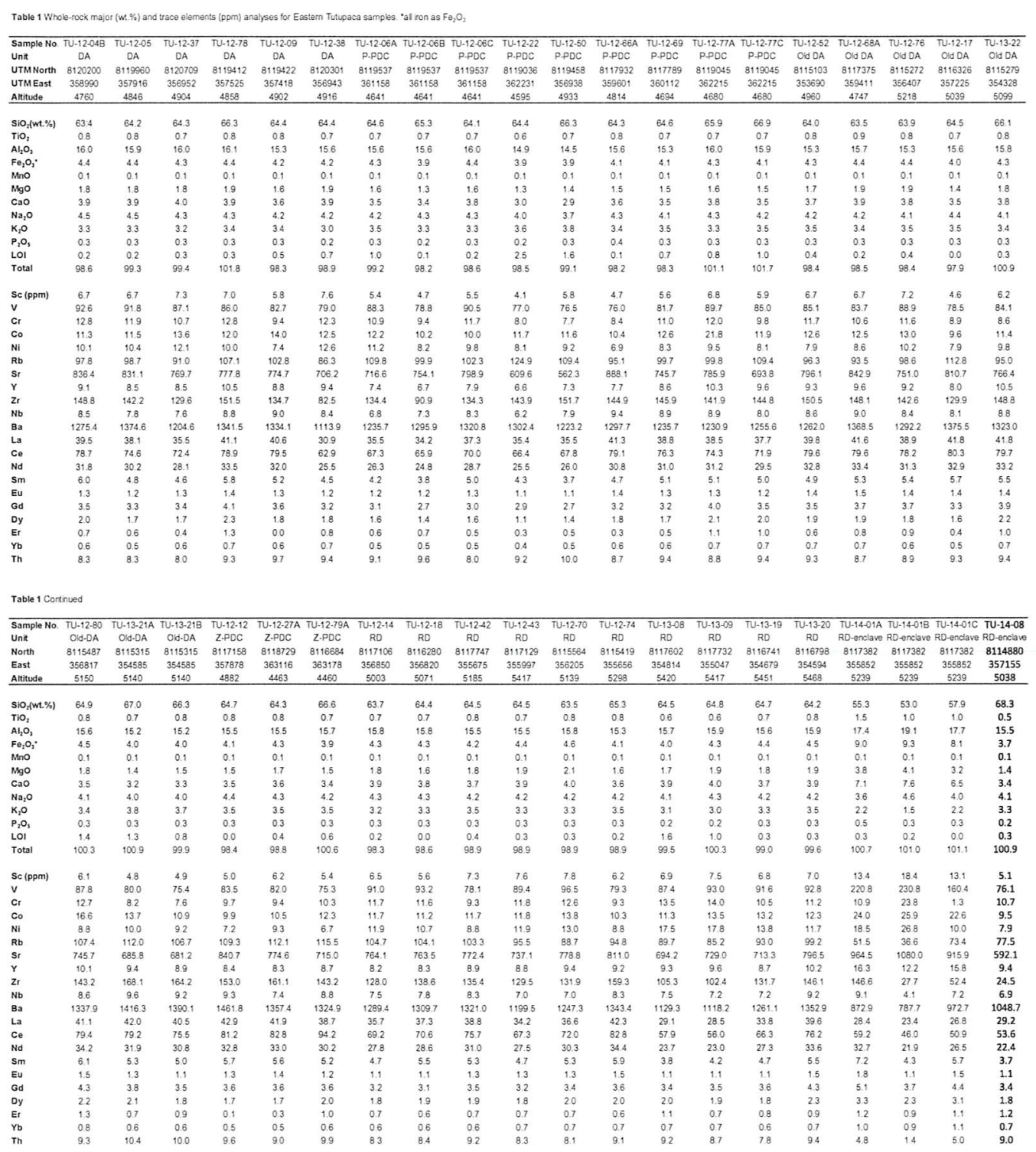




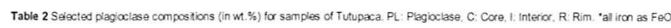

\begin{tabular}{|c|c|c|c|c|c|c|c|c|c|c|c|c|c|c|c|c|c|}
\hline \multirow{2}{*}{$\begin{array}{l}\text { Sample No, } \\
\text { Description } \\
\text { Anarsse No. }\end{array}$} & \multirow{2}{*}{ 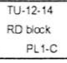 } & \multirow[b]{2}{*}{ PL1-R } & \multirow{2}{*}{\multicolumn{5}{|c|}{$\begin{array}{l}\text { TU-12.22 } \\
\text { RD bick }\end{array}$}} & \multicolumn{3}{|c|}{$\begin{array}{l}\text { TU-12-42 } \\
\text { RO b-bock }\end{array}$} & \multicolumn{5}{|c|}{$\begin{array}{l}\text { TU.12.7TC } \\
\text { P.PDC DOAmb }\end{array}$} & \multirow[b]{2}{*}{ PL2.1 } & \multirow[b]{2}{*}{$P L 2, R$} \\
\hline & & & PLLCC & PLLR & PL1.C & $P_{11-R}$ & & $P L 2 \cdot R$ & PL2.C & PL2:R & PLACC & PLLR & & $\mathrm{P} L 1-R$ & $P L 2 . C$ & & \\
\hline $\mathrm{SiO}_{3}$ & 60.8 & 542 & 612 & 549 & 61.7 & 60.1 & 552 & 560 & 59.8 & 597 & 616 & 61.7 & 618 & 57.5 & 568 & 61.6 & 568 \\
\hline $\mathrm{riO}_{2}$ & 0.0 & 0.0 & 0.0 & 0.0 & 0.0 & 0.0 & 0.0 & 0.0 & 00 & 0.0 & 00 & 00 & 00 & 0.0 & 0.0 & 0.0 & 0.1 \\
\hline $\mathrm{Al}_{2} \mathrm{O}_{3}$ & 24.4 & 282 & 23.6 & 26.8 & 237 & 24.4 & 27.7 & 27.5 & 250 & 24.5 & 238 & 23.9 & 240 & 25.8 & 27.5 & 24.1 & 25.6 \\
\hline Feor & 0.3 & 0.5 & 0.2 & 0.4 & 0.1 & 0.2 & 0.3 & 0.4 & 0.2 & 02 & 0.2 & 02 & 0.2 & 0.4 & 0.2 & 0.1 & 0.5 \\
\hline Mno & 0.0 & 0.0 & 0.0 & 0.0 & 0.0 & 0.0 & 0.0 & 0.0 & 0.0 & 0.0 & 0.0 & 0.0 & 0.0 & 00 & 0.0 & 0.0 & 00 \\
\hline Mgo & 0.0 & 0.1 & 0.0 & 0.0 & 0.0 & 00 & 0.0 & 0.0 & 0.0 & 0.0 & 0.0 & 0.0 & 0.0 & 0.0 & 0.0 & 0.0 & 0.1 \\
\hline $\mathrm{CaO}$ & 6.0 & 11.2 & 58 & 10.3 & 56 & 67 & 10.4 & 10.0 & 67 & 6.6 & 5.3 & 58 & 5.8 & 82 & 9.7 & 58 & 90 \\
\hline $\mathrm{Na}_{2} \mathrm{O}$ & 7.5 & 49 & 7.7 & 5.3 & 77 & 73 & 5.2 & 5.5 & 71 & 72 & 7.5 & 7.6 & 77 & 62 & 56 & 7.6 & 53 \\
\hline $\mathrm{K}_{2} \mathrm{O}$ & 0.9 & 0.3 & 0.9 & 0.4 & 0.9 & 0.7 & 0.4 & 0.4 & 0.6 & 0.7 & 1.0 & 0.8 & 0.8 & 0.6 & 0.4 & 0.8 & 0.7 \\
\hline Total & 99.8 & 99.3 & 99.3 & 982 & 997 & 99.5 & 99.3 & 100.0 & 99.5 & 990 & 99.3 & 1000 & 100.2 & 989 & 1002 & 1002 & 98.2 \\
\hline $\operatorname{An}(\%)$ & 290 & 55.0 & 27.9 & 50.5 & 27.1 & 32.5 & 51.2 & 488 & 328 & 32.2 & 264 & 28.1 & 230 & 40.6 & 47.8 & 28.3 & 46.4 \\
\hline $\mathrm{Ab}(\%)$ & 660 & 43.0 & 67.1 & 47.2 & 679 & 63.4 & 46.4 & 48.6 & 63.4 & 63.6 & 679 & 67.3 & 672 & 558 & 50.1 & 672 & 49.4 \\
\hline
\end{tabular}

\begin{tabular}{|c|c|c|c|c|c|c|c|c|c|c|c|c|c|c|c|c|c|}
\hline \multirow{2}{*}{$\begin{array}{l}\text { Sample No. } \\
\text { Description } \\
\text { A Aarysse Ho. }\end{array}$} & \multirow{2}{*}{$\begin{array}{l}\text { TU-12-06A } \\
\text { P.PPC bamb } \\
\text { PLL2.C }\end{array}$} & \multirow[b]{2}{*}{ PLIR R } & \multirow[b]{2}{*}{$P L 4 C$} & \multirow[b]{2}{*}{ PLAR } & \multirow[b]{2}{*}{ PL18CC } & \multirow[b]{2}{*}{ PL18-1 } & \multirow[b]{2}{*}{$P$ PLBR } & \multirow[b]{2}{*}{ PL19G C } & \multicolumn{3}{|c|}{$\begin{array}{l}\text { TU.14-01A } \\
\text { Enclare i R R black }\end{array}$} & \multirow[b]{2}{*}{ PLSCC } & \multirow[b]{2}{*}{ PLSR } & \multirow{2}{*}{\multicolumn{2}{|c|}{$\begin{array}{l}\text { TU-14.08 } \\
\text { Sulceous enclave in RD biock }\end{array}$}} & \multirow[b]{2}{*}{ PLS-C } & \multirow[b]{2}{*}{ PLSR } \\
\hline & & & & & & & & & PL19R & 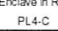 & PLAR & & & & & & \\
\hline $\mathrm{SiO}_{2}$ & 61.4 & 54.7 & $\infty 0.9$ & 547 & 609 & 60.2 & 59.3 & 58.5 & 59.8 & 61.7 & 599 & 54.3 & 60.6 & 60.6 & 59.3 & 61.3 & 61.2 \\
\hline $\mathrm{TiO}_{2}$ & 0.1 & 00 & 00 & 0.0 & 0.0 & 0.0 & 0.0 & 0.0 & 00 & 0.0 & 0.1 & 0.0 & 0.1 & 0.0 & 0.0 & 0.1 & 0.0 \\
\hline $\mathrm{Al}_{2} \mathrm{O}_{2}$ & 23.8 & 27.8 & 24.8 & 27.9 & 24.5 & 24.5 & 25.0 & 254 & 250 & 237 & 247 & 28.4 & 245 & 24.7 & 25.8 & 24.5 & 24.6 \\
\hline $\mathrm{FeO} \mathrm{O}^{\circ}$ & 0.2 & 0.5 & 0.2 & 0.5 & 0.2 & 02 & 0.4 & 0.4 & 0.4 & 0.1 & 0.2 & 0.4 & 0.4 & 0.2 & 02 & 0.2 & 02 \\
\hline Mno & 0.0 & 0.0 & 0.0 & 0.0 & 0.0 & 0.0 & 0.0 & 0.0 & 0.0 & 0.0 & 0.0 & 0.0 & 0.0 & 00 & 00 & 0.0 & 00 \\
\hline MgO & 0.0 & 0.1 & 0.0 & 0.0 & 0.0 & 0.0 & 0.0 & 0.0 & 0.0 & 0.0 & 0.0 & 0.0 & 0.0 & 0.0 & 00 & 0.0 & 00 \\
\hline caO & 5.7. & 10.6 & 67 & 111 & 6.3 & 6.7 & 76 & 8.0 & 12 & 5.6 & 6.7 & 11.0 & 6.5 & 6.5 & 77 & 6.1 & 64 \\
\hline $\mathrm{N}_{2} \mathrm{O}$ & 77 & 51 & 61 & 47 & 74 & 70 & 66 & 62 & 66 & 77 & 7.0 & 50 & 7.1 & 7.3 & 69 & 7.3 & 7.5 \\
\hline $\mathrm{K}_{2} \mathrm{O}$ & 0.8 & 0.4 & 0.7 & 0.4 & 0.8 & 0.7 & 0.9 & 0.9 & 1.1 & 0.9 & 0.7 & 0.3 & 0.7 & 0.7 & 0.5 & 0.7 & 0.7 \\
\hline Total & 99.5 & 99.3 & 99.4 & 99.4 & 100.0 & 99.3 & 99.8 & 99.5 & 100.2 & 99.7 & 992 & 90.5 & 993 & 100.1 & 1003 & 1002 & 100.7 \\
\hline An (\%) & 27.8 & 52.1 & 55.0 & 550 & 30.6 & 33.2 & 36.9 & 39.4 & 352 & 27.1 & 332 & 54.0 & 320 & 31.8 & 37.3 & 303 & 308 \\
\hline $\mathrm{Ab}(\%)$ & 67.6 & 45.5 & 42.5 & 42.5 & 649 & 62.6 & 57.9 & 55.3 & 58.3 & 67.9 & 627 & 4.5 & 639 & 639 & 598 & 655 & 653 \\
\hline
\end{tabular}




\begin{tabular}{|c|c|c|c|c|c|c|c|c|c|c|c|c|c|c|c|c|}
\hline \multirow{2}{*}{$\begin{array}{l}\text { Sample No. } \\
\text { Description } \\
\text { Analyse No. }\end{array}$} & \multicolumn{4}{|l|}{ TU-12-14 } & \multicolumn{4}{|l|}{$T \mathrm{TV} \cdot 1242$} & \multicolumn{4}{|l|}{$T U-12-70$} & \multicolumn{4}{|l|}{ TU-12.06A } \\
\hline & $\begin{array}{l}\text { RO block } \\
\text { ANFH1-C }\end{array}$ & AMPH1-R & AMPH2CC & AMPH2-R & $\begin{array}{l}\text { RD block } \\
\text { AMPH1-C }\end{array}$ & ANPHI-R & АМРHZ-MC & $A M P H 2 M R$ & & АМРН1.R & АМРНЗМС & AMPH3-MR & $\begin{array}{l}\text { P.PDC bomb } \\
\text { AMPH1.C }\end{array}$ & ANDH1-R & АNPHAC C & ANPHARR \\
\hline $\mathrm{SiO}_{2}$ & 460 & 46.3 & 47.2 & 455 & 46.9 & 46.3 & 46.6 & 42.9 & 46.3 & 478 & 42.6 & 425 & 41.9 & 40.6 & 47.1 & 43.4 \\
\hline $\mathrm{riO}_{\mathrm{i}}$ & 1.2 & 1.3 & 1.5 & 1.4 & 1.3 & 1.3 & 1.4 & 3.3 & 1.4 & 1.1 & 3.2 & 3.3 & 3.2 & 3.0 & 1.2 & 2.9 \\
\hline $\mathrm{Al}_{2} \mathrm{O}_{3}$ & 7.6 & 73 & 69 & 77 & 70 & 7.3 & 72 & 10.5 & 7.7 & 6.7 & 10.5 & 108 & 12.0 & 12.0 & 7.0 & 10.1 \\
\hline $\mathrm{FeO}^{\circ}$ & 154 & 149 & 14.8 & 15.5 & 14.8 & 14.6 & 15.1 & 12.3 & 15.2 & 138 & 12.2 & 11.6 & 13.0 & 15.6 & 14.3 & 13.4 \\
\hline Mno & 0.4 & 0.5 & 04 & 0.3 & 0.5 & 0.4 & 0.4 & 0.2 & 0.4 & 0.4 & 0.1 & 0.1 & 0.1 & 0.3 & 0.4 & 0.2 \\
\hline $\mathrm{Mgo}$ & 127 & 12.8 & 132 & 126 & 129 & 13.0 & 130 & 138 & 125 & 138 & 138 & 14.4 & 13.0 & 11.0 & 13.3 & 13.3 \\
\hline cao & 11.7 & 11.6 & 11.7 & 11.7 & 11.8 & 11.3 & 11.6 & 11.5 & 11.9 & 117 & 112 & 11.5 & 11.6 & 11.5 & 11.5 & 11.2 \\
\hline $\mathrm{Na}_{2} \mathrm{O}$ & 14 & 1.3 & 13 & 1.5 & 1.3 & 1.4 & 13 & 23 & 15 & 1.3 & 2.4 & 2.4 & 2.4 & 2.2 & 1.7 & 2.3 \\
\hline $\mathrm{K}_{2} \mathrm{O}$ & 0.8 & 0.8 & 0.7 & 0.9 & 0.7 & 0.8 & 0.8 & 09 & 08 & 0.7 & 0.9 & 0.8 & 09 & 1.0 & 0.7 & 0.9 \\
\hline Total & 973 & 969 & 97.7 & 971 & 972 & 965 & 973 & 97.6 & 97.6 & 97.4 & 970 & 974 & 98.1 & 97.1 & 97.2 & 97.6 \\
\hline Mg\# & 595 & 60.4 & 61.3 & 591 & 60.9 & 613 & 60.6 & 66.6 & 59.5 & 64.1 & 66.8 & 68.9 & 64.1 & 55.7 & 62.4 & 63.9 \\
\hline $\mathrm{N}_{\mathrm{Al}}$ & 1.2 & 12 & 1.1 & 1.2 & 1.1 & 11 & 1.1 & 1.7 & 1.2 & 1.0 & 1.7 & 18 & 1.9 & 1.9 & 1.1 & 1.6 \\
\hline nAI & 0.1 & 0.1 & 0.1 & 0.1 & 0.1 & 0.1 & 0.1 & 0.1 & 0.2 & 0.2 & 0.1 & 0.1 & 0.2 & 0.2 & 0.1 & 0.1 \\
\hline \multicolumn{17}{|c|}{ Table 3 Continued } \\
\hline Sample No. & Tu-12.77c & & & & & & & & \multirow{2}{*}{\multicolumn{4}{|c|}{$\begin{array}{l}\text { Tu-14.01 } \\
\text { Encture h RD Dobok }\end{array}$}} & \multicolumn{4}{|l|}{ TU-14:.68 } \\
\hline Description & P.PDC bomb & & & & & & & & & & & & Silcesus encial & e in $R D$ block & & \\
\hline Analyse No. & ANPH1-C & $A M P H 1 \cdot R$ & AMPH2C & ANOH $2 \cdot R$ & ANPH3-C & AVPH3.R & ANPHA-C & AMPHAR & ANPHI-C & ANPH1-R & ANPHACC & ANPH3:R & AMPHI-C & ANPH1:R & ANPH1-C & ANPH1-R \\
\hline sio, & 46.6 & 45.4 & 46.9 & 424 & 48.3 & 46.5 & 45.4 & 43.3 & 42.4 & 425 & 42.5 & 42.5 & 476 & 46.7 & 49.7 & 47.3 \\
\hline Tio, & 1.1 & 1.3 & 1.4 & 30 & 1.0 & 1.3 & 1.5 & 29 & 3.2 & 2.5 & 2.8 & 30 & 1.2 & 1.3 & 1.1 & 1.3 \\
\hline $\mathrm{Al}_{2} \mathrm{O}$ & $7: 1$ & 77 & 68 & 109 & 5.6 & 7.4 & 8.2 & 10.6 & 11.3 & 11.8 & 120 & 115 & 7.1 & 7.5 & 5.7 & 7.2 \\
\hline $\mathrm{FeO}^{\circ}$ & 15.1 & 15.7 & 15.1 & 13.6 & 14.0 & 14.6 & 15.7 & 12.5 & 11.6 & 13.9 & 13.8 & 11.8 & 14.9 & 15.2 & 14.0 & 15.1 \\
\hline Mno & 0.5 & 0.4 & 0.4 & 0.2 & 0.5 & 0.3 & 0.4 & 0.2 & 0.1 & 0.3 & 0.2 & 0.2 & 0.5 & 0.4 & 0.5 & 0.5 \\
\hline $\mathrm{MgO}$ & 128 & 12.3 & 13.0 & 13.0 & 14.3 & 12.8 & 12.4 & 13.6 & 142 & 12.7 & 12.7 & 13.7 & 13.3 & 12.8 & 14.2 & 130 \\
\hline CaO & 11.3 & 11.5 & 11.3 & 11.1 & 11.5 & 11.3 & 11.2 & 11.1 & 11.0 & 11.1 & 11.2 & 11.3 & 11.8 & 11.8 & 11.6 & 11.4 \\
\hline $\mathrm{Na}_{2} \mathrm{O}$ & 1.3 & 1.6 & 1.3 & 2.3 & 1.1 & 1.3 & 1.5 & 2.1 & 23 & 2.1 & 2.2 & 22 & 1.3 & 1.3 & 1.1 & 1.4 \\
\hline $\mathrm{K}_{2} \mathrm{O}$ & 0.7 & 0.8 & 0.7 & 0.9 & 0.6 & 0.7 & 0.9 & 0.8 & 0.8 & 0.9 & 0.9 & 0.8 & 0.7 & 0.8 & 0.5 & 0.7 \\
\hline Total & 96.7 & 967 & 968 & 97.3 & 96.9 & 96.4 & 972 & 97.2 & 969 & 978 & 99.3 & 97.1 & 98.4 & 97.8 & 58.4 & 979 \\
\hline Mg\# & 60.1 & 59.2 & 60.6 & 63.1 & 64.5 & 610 & 58.5 & 60.0 & 686 & 62.0 & 62.1 & 67.4 & 61.3 & 60.1 & 64.4 & 605 \\
\hline $\mathrm{N}_{\mathrm{AI}}$ & 1. & 12 & 1.1 & 1.8 & 0.9 & 1.1 & 1.3 & 17 & 1.8 & 1.8 & 1.8 & 18 & 1.1 & 1.2 & 09 & 1.1 \\
\hline${ }^{A \mathrm{AI}}$ & 0.1 & 0.1 & 0.1 & 0.9 & 0.0 & 0.2 & 0.9 & 0.2 & 0.1 & 0.2 & 0.2 & 02 & 0.1 & 0.9 & 0.1 & 0.1 \\
\hline
\end{tabular}




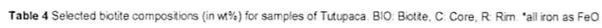

\begin{tabular}{|c|c|c|c|c|c|c|c|c|c|c|c|c|c|c|c|c|}
\hline $\begin{array}{l}\text { Sample No. } \\
\text { Description }\end{array}$ & $\begin{array}{l}\text { TU-12-14 } \\
\text { RD block }\end{array}$ & & & & & & $\begin{array}{l}\text { Tu-1242 } \\
\text { RD bock }\end{array}$ & & 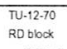 & & $\begin{array}{l}\text { TU.12-1208A } \\
\text { P.PDC bon: }\end{array}$ & & & & $\begin{array}{l}\text { TU-12.77C } \\
\text { P.PDC bonb }\end{array}$ & \\
\hline Analyse No. & Bion-C & $8101 \cdot R$ & B102-C & $B 102-R$ & B:03.c & $B 103 \cdot R$ & Bion-C & Bilo1-R & Bio1-C & $B 101 \cdot R$ & Bio1-C & $B 101-R$ & $8102 . C$ & $B 102 . R$ & Bion-C & $B 101-R$ \\
\hline $\mathrm{SiO}_{2}$ & 36.5 & 365 & 365 & 36.1 & 36.4 & 36.1 & 36.7 & 36.6 & 368 & 36.7 & 372 & 37.4 & 36.7 & 38.3 & 36.7 & 37.0 \\
\hline $\mathrm{TiO}_{2}$ & 45 & 45 & 44 & 45 & 41 & 4.2 & 4.2 & 4.3 & 4.6 & 4.6 & 4.2 & 4.5 & 4.2 & 4.5 & 4.3 & 4.2 \\
\hline $\mathrm{Al}_{2} \mathrm{O}_{1}$ & 13.5 & 13.3 & 13.2 & 13.3 & 13.5 & 134 & 13.3 & 13.5 & 13.5 & 132 & 13.4 & 13.7 & 13.5 & 14.3 & 13.4 & 13.1 \\
\hline $\mathrm{FeO}^{\circ}$ & 18.5 & 17.2 & 17.6 & 16.6 & 19.4 & 188 & 18.2 & 16.8 & 186 & 18.6 & 18.4 & 15.1 & 184 & 108 & 19.1 & 190 \\
\hline Mno & 0.2 & 02 & 0.2 & 0.2 & 0.3 & 0.2 & 0.2 & 0.2 & 0.2 & 0.2 & 0.3 & 0.2 & 22 & 0.1 & 0.2 & 0.2 \\
\hline mgo & 12.6 & 13.2 & 134 & 13.6 & 12.0 & 12.6 & 12.4 & 13.5 & 124 & 12.5 & 12.8 & 15.1 & 12.6 & 17.8 & 12.6 & 127 \\
\hline cao & 0.0 & 00 & 00 & 0.0 & 00 & 0.1 & 0.0 & 00 & 00 & 0.0 & 0.0 & 00 & 0.0 & 0.0 & 0.0 & 0.0 \\
\hline $\mathrm{Na}_{1} \mathrm{O}$ & 0.6 & 0.6 & 0.7 & 0.7 & 0.6 & 0.7 & 0.5 & 0.6 & 0.5 & 0.6 & 0.6 & 0.7 & 07 & 0.7 & 0.3 & 0.4 \\
\hline $\mathrm{K}_{2} \mathrm{O}$ & 9.1 & 9.0 & 90 & 8.8 & 9.1 & 92 & 9.1 & 92 & 9.4 & 93 & 9.8 & 9.3 & 9.3 & 93 & 9.1 & 9.5 \\
\hline Total & 95. & 94. & 950 & 939 & 95.5 & 95.3 & 94.6 & 94.8 & 960 & 958 & 96,7 & 960 & 95.5 & 958 & 958 & 96.3 \\
\hline
\end{tabular}




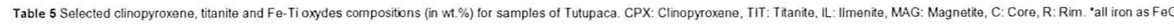

\begin{tabular}{|c|c|c|c|c|c|c|c|c|c|c|c|c|c|c|}
\hline $\begin{array}{l}\text { Sample No. } \\
\text { Description }\end{array}$ & $\begin{array}{l}\text { TU-12-42 } \\
\text { RD block }\end{array}$ & & & & $\begin{array}{l}\text { Tu-12.06A } \\
\text { P.PDC bomb }\end{array}$ & & & & $\begin{array}{l}\text { TU-12-06A } \\
\text { P.PDC bomb }\end{array}$ & & $\begin{array}{l}\text { TU-12-42 } \\
\text { RD block }\end{array}$ & & & \\
\hline Analyse No. & CPX1-C & $\mathrm{CPX} 1 \cdot \mathrm{R}$ & $\mathrm{CPX2}-\mathrm{C}$ & $\mathrm{CP} \times 2-\mathrm{R}$ & $\mathrm{CPX1} \cdot \mathrm{C}$ & $C P X 1-R$ & $\mathrm{CP} \times 2-\mathrm{C}$ & $\mathrm{CP} \times 2 \cdot R$ & $\mathrm{TIT- \textrm {C } _ { 1 }}$ & IIT-81 & $T I T \cdot C 1$ & $T \pi \cdot 81$ & $\mathrm{TIT} \cdot \mathrm{Cl}_{2}$ & $T \pi \cdot 82$ \\
\hline $\mathrm{SiO}_{2}$ & 52.6 & 510 & 53.4 & 53.2 & 51.5 & 52.9 & 50.9 & 52.1 & 29.7 & 30.1 & 29.5 & 29.5 & 29.8 & 30.1 \\
\hline $\mathrm{TiO}_{2}$ & 0.5 & 0.9 & 0.3 & 0.5 & 0.7 & 0.6 & 0.7 & 0.6 & 38.0 & 37.3 & 37.4 & 37.4 & 36.6 & 378 \\
\hline $\mathrm{Al}_{2} \mathrm{O}_{3}$ & 1.8 & 3.2 & 0.5 & 0.7 & 3.2 & 2.3 & 3.3 & 2.5 & 0.8 & 12 & 1.1 & 1.1 & 1.3 & 1.1 \\
\hline $\mathrm{FeO}^{\circ}$ & 9.5 & 8.4 & 9.2 & 10.2 & 8.0 & 7.4 & 8.5 & 8.0 & 1.3 & 1.8 & 1.4 & 1.4 & 1.7 & 1.3 \\
\hline Mno & 0.2 & 0.2 & 0.2 & 0.2 & 0.1 & 0.1 & 0.2 & 0.1 & 0.1 & 0.0 & 0.1 & 0.1 & 0.1 & 0.1 \\
\hline Mgo & 16.6 & 14.6 & 14.6 & 15.1 & 15.0 & 15.8 & 15.0 & 15.4 & 0.0 & 0.0 & 0.0 & 0.0 & 0.0 & 0.0 \\
\hline cao & 17.9 & 20.3 & 21.2 & 19.5 & 20.4 & 20.8 & 202 & 20.0 & 27.4 & 27.7 & 27.0 & 27.0 & 26.8 & 27.6 \\
\hline $\mathrm{Na}_{2} \mathrm{O}$ & 0.4 & 0.5 & 0.4 & 0.4 & 0.5 & 0.5 & 0.4 & 0.5 & 0.1 & 0.0 & 0.0 & 0.0 & 0.0 & 0.0 \\
\hline $\mathrm{K}_{2} \mathrm{O}$ & 0.0 & 0.0 & 0.0 & 0.0 & 0.0 & 0.1 & 0.0 & 0.1 & 0.0 & 0.0 & 0.0 & 0.0 & 0.0 & 0.0 \\
\hline Total & 99.6 & 99.1 & 99.8 & 99.8 & 99.5 & 100.3 & 99.2 & 99.3 & 97.5 & 98.0 & 96.6 & 96.6 & 962 & 98.1 \\
\hline En (\%) & 47.6 & 43.0 & 41.8 & 43.3 & 44.0 & 45.2 & 43.8 & 44.9 & & & & & & \\
\hline Fs & 15.4 & 13.8 & 14.8 & 16.4 & 13.2 & 11.9 & 13.9 & 13.2 & . & . & & & & \\
\hline wo & 37.0 & 43.1 & 43.4 & 40.3 & 42.8 & 42.9 & 42.3 & 41.9 & & . & . & & . & \\
\hline $\mathrm{Mg} \#$ & 75.6 & 75.7 & 73.9 & 72.5 & 76.9 & 79.2 & 75.9 & 77.3 & & & . & & & \\
\hline
\end{tabular}

\begin{tabular}{|c|c|c|c|c|c|c|c|c|c|c|c|c|c|}
\hline \multirow{2}{*}{$\begin{array}{l}\text { Sample No. } \\
\text { Description } \\
\text { Analyse No. }\end{array}$} & \multicolumn{4}{|l|}{ TU-14-08 } & \multicolumn{2}{|l|}{$\begin{array}{l}\text { TU-12.77C } \\
\text { P.PDC Domb }\end{array}$} & \multicolumn{2}{|l|}{$\begin{array}{l}\text { TU-12-14 } \\
\text { RD block }\end{array}$} & \multicolumn{2}{|l|}{ TU-12-42 } & \multicolumn{3}{|c|}{$\begin{array}{l}\text { TU-14-01 } \\
\text { Enclave in RD block }\end{array}$} \\
\hline & TTN.C1 & TTN.B1 & TTN-C2 & TTN.B2 & II.C1 & L-B1 & MAG-C2 & MAG-B2 & MAG.C1 & MAG-B1 & Il.C1 & IL-C2 & II-B2 \\
\hline $\mathrm{SiO}_{2}$ & 29.8 & 29.8 & 29.4 & 29.9 & 0.0 & 0.0 & 0.1 & 0.4 & 0.1 & 0.1 & 0.0 & 0.0 & 0.0 \\
\hline $\mathrm{TiO}_{2}$ & 37.2 & 36.6 & 36.9 & 37.4 & 35.0 & 35.2 & 3.8 & 3.7 & 8.5 & 11.4 & 44.6 & 34.1 & 50.6 \\
\hline $\mathrm{Al}_{2} \mathrm{O}_{3}$ & 1.0 & 1.2 & 1.1 & 1.1 & 0.3 & 0.2 & 1.2 & 1.5 & 1.9 & 1.4 & 0.1 & 0.4 & 0.1 \\
\hline $\mathrm{FeO} \mathrm{O}^{\circ}$ & 1.4 & 1.9 & 1.5 & 1.5 & 58.2 & 59.3 & 87.2 & 84.9 & 79.9 & 79.1 & 52.4 & 57.5 & 45.6 \\
\hline MnO & 0.1 & 0.1 & 0.1 & 0.1 & 0.5 & 0.6 & 0.4 & 0.4 & 0.6 & 0.7 & 0.7 & 0.5 & 0.6 \\
\hline $\mathrm{MgO}$ & 0.0 & 0.0 & 0.0 & 0.0 & 2.2 & 1.0. & 0.9 & 0.8 & 1.9 & 1.7 & 1.8 & 1.2 & 1.2 \\
\hline CaO & 27.1 & 27.3 & 26.6 & 27.4 & 0.1 & 0.3 & 0.0 & 0.1 & 0.0 & 0.1 & 0.0 & 0.0 & 0.0 \\
\hline $\mathrm{Na}_{2} \mathrm{O}$ & 0.1 & 0.0 & 0.0 & 0.0 & 0.0 & 0.0 & 0.0 & 0.1 & 0.0 & 0.0 & 0.0 & 0.0 & 0.1 \\
\hline $\mathrm{K}_{2} \mathrm{O}$ & 0.0 & 0.0 & 0.0 & 0.0 & 0.0 & 0.0 & 0.0 & 0.1 & 0.1 & 0.0 & 0.0 & 0.0 & 0.0 \\
\hline Total & 96.7 & 97.0 & 95.5 & 97.5 & 96.3 & 96.6 & 93.6 & 91.9 & 93.0 & 94.5 & 99.7 & 93.7 & 98.2 \\
\hline Mg\# & & . & & & & . & & $\cdots$ & & & . & . & . \\
\hline
\end{tabular}


Table 6 Matrix glass and melt inclusions compositions (average \pm standard deviation) for Tutupaca samples. *all iron as FeO

$\begin{array}{lcccccc}\begin{array}{l}\text { Sample No. } \\ \text { Description }\end{array} & \begin{array}{c}\mathrm{TU}-12-42 \\ \mathrm{RD} \text { block }\end{array} & \begin{array}{c}\mathrm{TU}-12-06 \mathrm{~A} \\ \mathrm{P}-\mathrm{PDC} \text { bomb }\end{array} & \begin{array}{c}\mathrm{TU}-12-77 \mathrm{C} \\ \mathrm{P}-\mathrm{PDC} \text { bomb }\end{array} & \begin{array}{c}\text { TU-12-78 } \\ \text { DA block }\end{array} & \begin{array}{c}\text { TU-14-01 } \\ \text { Enclave in RD block }\end{array} & \begin{array}{c}\text { TU-12-77C } \\ \text { Ml in plagioclase }\end{array} \\ \mathrm{SiO}_{2} & 73.8 \pm 2.8 & 75.3 \pm 2.5 & 75.6 \pm 2.1 & 75.4 \pm 2.8 & 77.0 \pm 1.6 & 76.4 \pm 1.4 \\ \mathrm{TiO}_{2} & 0.1 \pm 0.1 & 0.3 \pm 0.1 & 0.4 \pm 0.1 & 0.3 \pm 0.1 & 0.2 \pm 0.1 & 0.1 \pm 0.06 \\ \mathrm{Al}_{2} \mathrm{O}_{3} & 15.1 \pm 2.8 & 12.1 \pm 1.7 & 11.7 \pm 1.5 & 13.4 \pm 1.5 & 12.6 \pm 0.9 & 12.3 \pm 0.3 \\ \mathrm{FeO}^{*} & 1.0 \pm 0.2 & 1.01 \pm 0.2 & 0.9 \pm 0.2 & 1.04 \pm 0.3 & 1.1 \pm 0.1 & 0.6 \pm 0.2 \\ \mathrm{MnO} & 0.05 \pm 0.02 & 0.04 \pm 0.04 & 0.1 \pm 0.1 & 0.02 \pm 0.03 & 0.03 \pm 0.03 & 0.04 \pm 0.04 \\ \mathrm{MgO} & 0.1 \pm 0.05 & 0.17 \pm 0.19 & 0.1 \pm 0.06 & 0.2 \pm 0.2 & 0.1 \pm 0.1 & 0.08 \pm 0.02 \\ \mathrm{CaO} & 1.7 \pm 1.6 & 1.0 \pm 0.8 & 0.7 \pm 0.5 & 1.0 \pm 0.8 & 0.5 \pm 0.1 & 0.4 \pm 0.1 \\ \mathrm{Na}{ }_{2} \mathrm{O} & 3.7 \pm 1.2 & 3.1 \pm 0.7 & 2.5 \pm 0.8 & 3.1 \pm 1.1 & 2.3 \pm 1.0 & 3.4 \pm 0.2 \\ \mathrm{~K}_{2} \mathrm{O} & 4.9 \pm 1.9 & 5.3 \pm 0.5 & 5.3 \pm 0.5 & 5.0 \pm 1.0 & 5.4 \pm 0.7 & 5.1 \pm 0.22 \\ \mathrm{Total} & 100.6 & 98.5 & 97.5 & 99.6 & 99.3 & 98.6 \pm 1.1\end{array}$

$\mathrm{H}_{2} \mathrm{O}$ (analysed by Raman spectrioscopy) 
Table 7 Pressure estimates based on Al-in-hornblende geobarometers. Barometers using total aluminium concentrations are temperature-dependent and should only be used for temperatures close to their calibration range. Barometers calibrated on rhyolitic and dacitic compositions cannot be used for the andesitic enclaves. Calculations that fit those quality criteria are reported in bold.

Batometers calibrated for dacites to rhyolites

$\begin{array}{lc}\text { Reference } & \text { Schmidt (1992) } \\ \text { Calibration T } & \sim 669^{\circ} \mathrm{C} \\ \begin{array}{l}\text { Dacites, low } \\ \text { Al }\left(735^{\circ} \mathrm{C}\right)\end{array} & 291 \pm 47 \mathrm{MPa} \\ \begin{array}{l}\text { Dacites, } \\ \text { high Al }\left(835^{\circ} \mathrm{C}\right)\end{array} & 561 \pm 134 \mathrm{MPa} \\ \text { Silicic enclave, low } & 305 \pm 48 \mathrm{MPa} \\ \begin{array}{l}\text { Al (735 } \\ \text { Mafic }\end{array} & \\ \text { Mafic enclave, } & \end{array}$

Johnson and

Juhnson and

Anderson ands$$
\sim 733^{\circ} \mathrm{C}
$$

$\sim 760^{\circ} \mathrm{C}$

$246 \pm 27 \mathrm{MPa}$

$180 \pm 42 \mathrm{MPa}$

$222 \pm 44 \mathrm{MPa}$

$440 \pm 105 \mathrm{MPa}$

$420 \pm 111 \mathrm{MPa}$

$210 \pm 83 \mathrm{MPa}$

$193 \pm 43 \mathrm{MPa}$

$227 \pm 44 \mathrm{MPa}$

$292 \pm 45 \mathrm{MPa}$ basalts to andesites

Ridolfi and Renzulli

Pennec (2019)

$T$ independent

(2012)

$\sim 936^{\circ} \mathrm{C}$

$230 \pm 58 \mathrm{MPa} \quad 97 \pm 20 \mathrm{MPa}$

$253 \pm 55 \mathrm{MPa}$

$218 \pm 80 \mathrm{MPa}$

$106 \pm 19 \mathrm{MPa}$

$244 \pm 18 \mathrm{MPa}$

$359 \pm 40 \mathrm{MPa}$

$254 \pm 59 \mathrm{MPa}$ 